\title{
فرقة اليهود المحافظة، ومقيلة أرض الميعاد
}

الباحثنة/ وفاء بنت عتبقا أبو عبيدمة الشريفا

المحاضرة بالجامعة السعودية الإكترونية

وباحثة الاكتور اة في جامعة أم القرى الإكئرون

\section{المقدمة}

الحمد الهه الواحد الأحد، الذي لم يلد ولم يولد، ولم يكن له كفواً أحد، و الصلاة

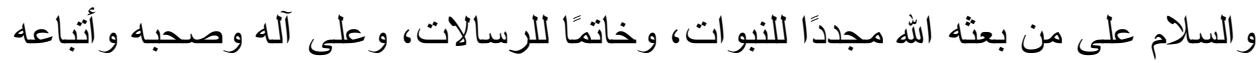
إلى يوم الدين، أما بعد:

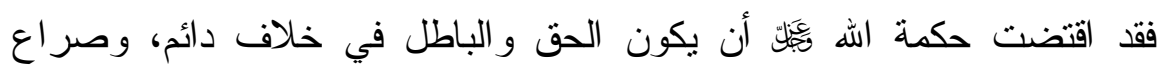
مستمر إلى أن يرث الله الأرض ومن عليها. ولقد بعث الله الأنبياء و المرسلين مبشرين ومنذرين،لتوحيد وعبادة الخالق داعين،

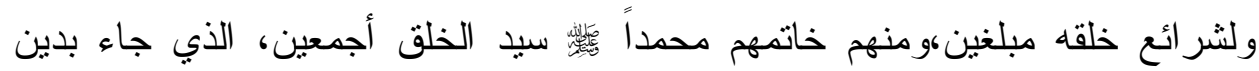

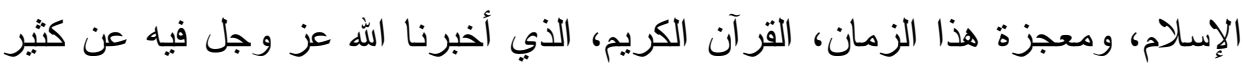
من عقائد و أخلاق اليهود وصفاتهم، ونهانا عن مسلك الأمم السابقة بالاختلاف و التغيير

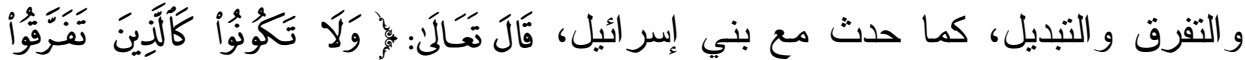

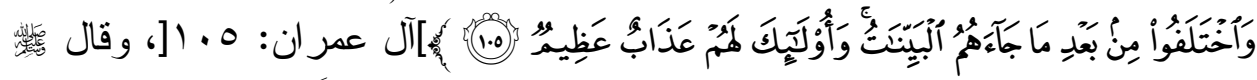

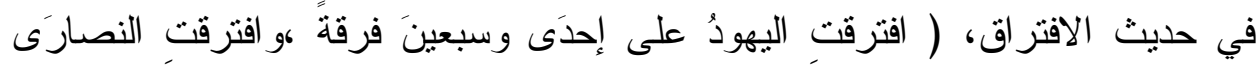

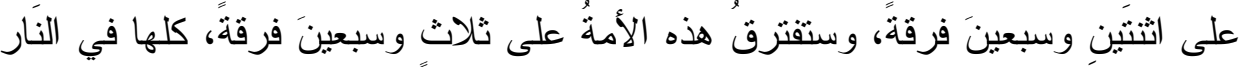
إلا و احدة) (')

وماز ال افتراق اليهود حتى عصرنا الحاضر، و الباحث في التاريخ اليهودي يجد

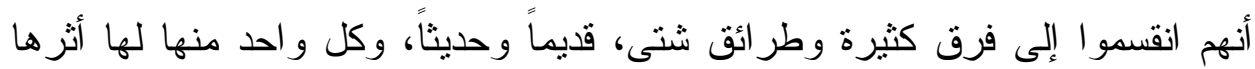
ونفوذها وأهدافها، ومن الفرق المعاصرة موضع الدراسة فرقة اليهود المحافظة، التي وني تُعد من أكبر و أهم الفرق اليهودية المعاصرة، ودالتي لله علاقة قوية بالصهيونية بشكل

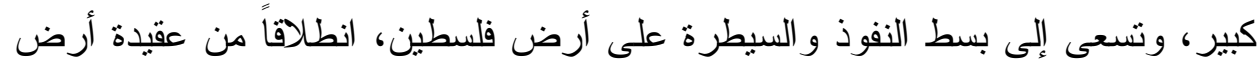


الميعاد التي تشترك فيها جميع الفرق اليهودية، وتسعى من خلال نصوصهم المقدسة

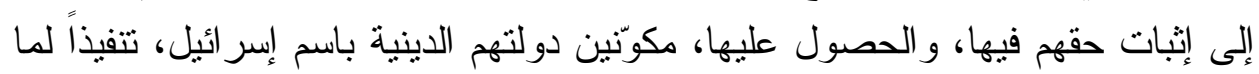
يسمى عندهم بإسر ائيل الكبرى.

و الصر اع بين الإسلام و اليهود قديم قدم الإسلام نفسه، فقد شاء الله عز وجل أن أن إنـاء

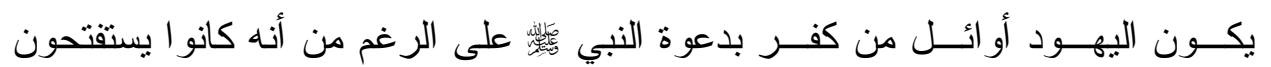

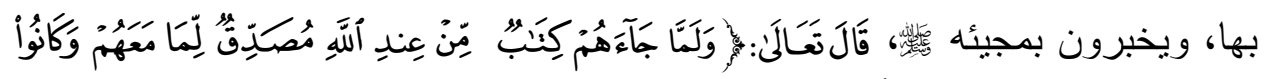

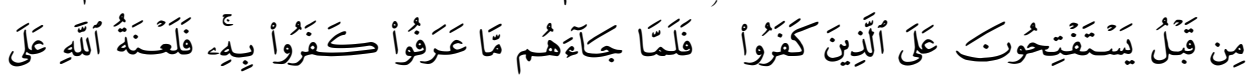

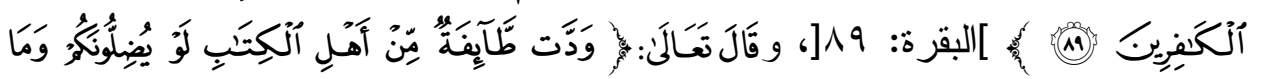

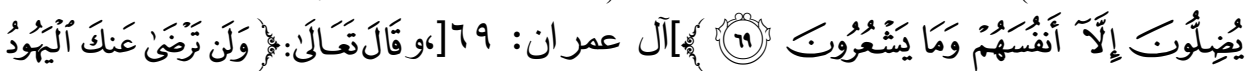

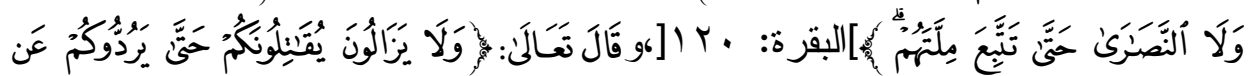

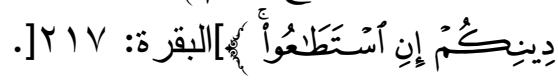

لذا سأحاول-بإذن الله- جاهدة من خلا هذه الدراسة الدة نسليط الضوء على بعض

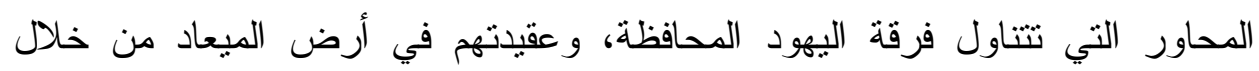
البحث في:نشأتهم، و أبرز أعلامهم، و أماكن انتشار هم، و علاقتهم بالصهيونية، ثم مناقثنة

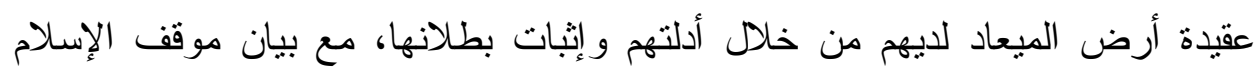

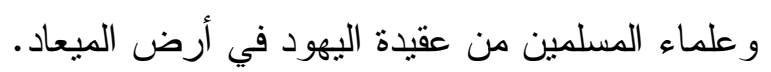
أهمية البحث: تتطلق أهمية البحث من أهمية الموضوع الذي يتتاوله و الذي يتمثل في عدة أمور () إن فرقة اليهود المحافظة من أكبر وأهم الفرق اليهودية المعاصرة، لما لها من أثز ونفوذ وعلاقة قوية بالفكر الصهيوني.

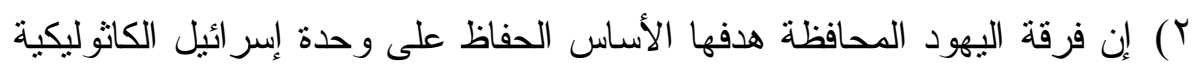
العالمية، و الحفاظ على استمر ارية التر اث اليهودي.

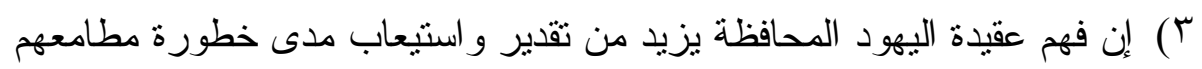
و أهدافهم، وجهودهم لتتبيت الكيان الصهيوني في فلسطين. 
§) إن الدولة اليهودية القائمة على أرض فلسطين هي كيان قائم على أساس

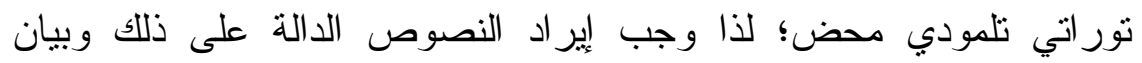
بطلانها وموقف علماء المسلمين منها. أهد اف البحث: يسعى هذا البحث لتحقيق عدة أهداف منها: () التعريف بنشأة فرقة اليهود المحافظة وأفكارهم وعقائدهم و أماكن انتشارهم، وأبرز أعلامهم.

r ب بيان العلاقة بين فرقة اليهود المحافظة و الصعيونية.

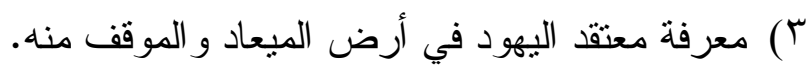

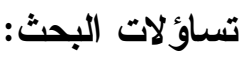
يسعى هذا البحث للإجابة على التساؤلات التالية:

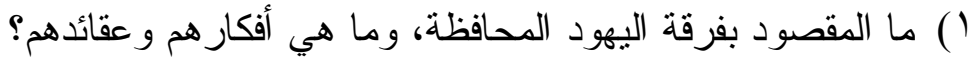

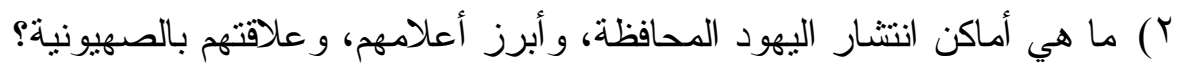

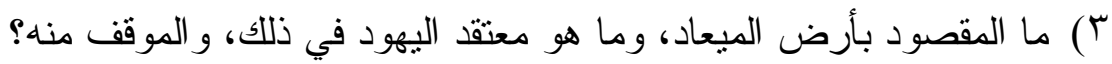

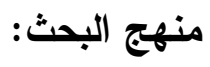

بناء على طبيعة هذا البحث، ونظراً لأن لكل بحث منهجاً بسلك، فستستخدم

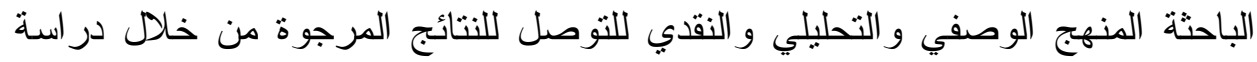
هذا الموضوع، والسير على إجر اءات وضو ابط البحث المتبعة.

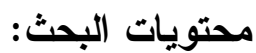

سيتكون البحث -بإذن الله-من مقدمة،ومبحثين، وخاتهــة، ثــ قائهــة بــالمر اجع، وفهرس للموضو عات. المقدمة وفيها:(أهمية البحث،أهداف البحث، تساؤلات البحــث، مـــهج البحـثن،

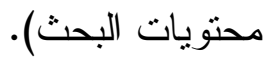
المبحث الأول: التعريف بفرقة اليهود المحافظة، وعلاقتهم بالصهيونية. المطلب الأول:نثأة فرقة اليهود المحافظة. المطلب الثاني:أبرز أعلام فرقة اليهود المحافظة وأماكن انتثارهم. المطلب الثالث: الفكر الديني لاى فرقة اليهود المحافظة وأبرز عقائدهم. 
المطلب الر ابع: علاقة اليهود المحافظة بالصهيونية و إسر ائيل.

المبحث الثاني:عقيدة أرض الميعاد لاى فرقة اليهود المحافظة والموقف منها.

$$
\text { المطلب الأول:مفهوم أرض الميعاد. }
$$

المطلب الثاني:معتقد اليهود في ارض الميعاد والموقف منه مــن خــلال كتـبـهم و أقو الهم.

المطلب الثالث: الموقف من عقيدة اليهود في أرض الميعاد. الخاتمة. قائمة المصادر والمر اجع. 
المبحث الأول: التعريف بفرقة اليهود المحافظة، وعلاقتهم بالصهيونية. المطلب الأول: نشأة فرقة اليهود المحافظة الئة

إن المتأمل في التاريخ المعاصر للحركات اليهودية الحديثة يجد أنها ظهرت كنتيجة مباشرة أو غير مباشرة لحركتين هما:

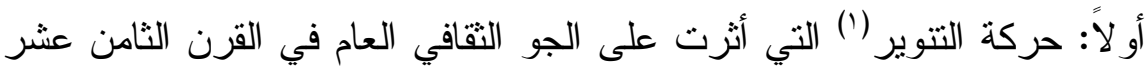

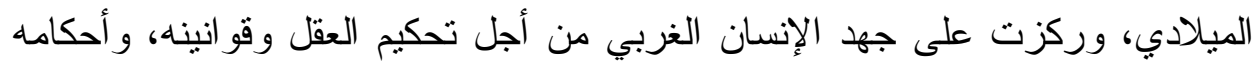

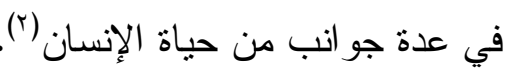

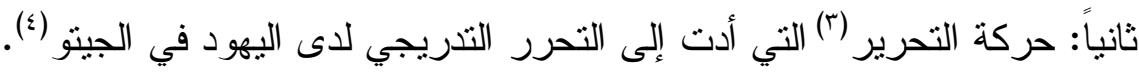

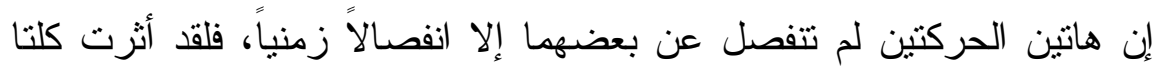

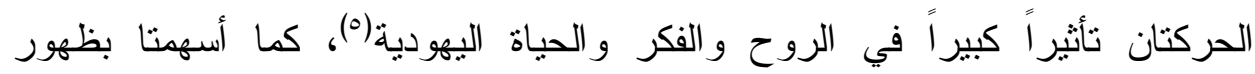
جماعات وحركات وفرق يهودية، لهم طرق مختلفة في أفكار هم وتوجهاتهم، وصياغة معتقاتهم، وطبيعة نظرتهم للأمور و المسائل المختلفة (7).

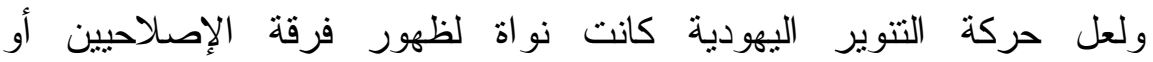
المجددين،التي قامت كرد فعل طبيعي لقرون التزمت و الظلمات، لذا كان الإصلاحية الإحيون

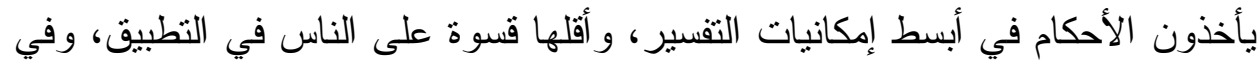

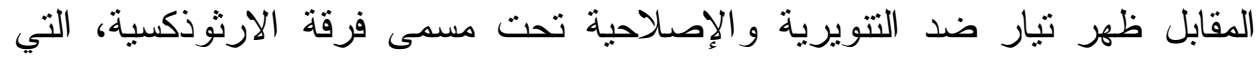

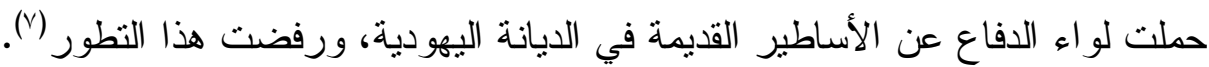

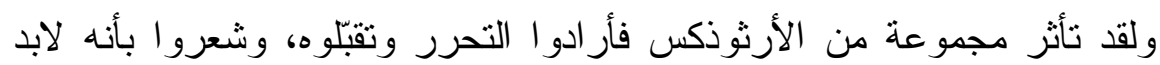

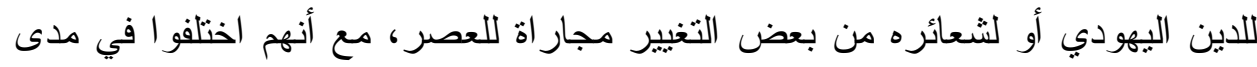
(') التتوير ، ظهر هذا المصطلح في القرنين الساد عشر والسابع عشر الميلاديين في أوربا وامتد بعد ذلك،، تعبيراً عن الفكر اللبرالي

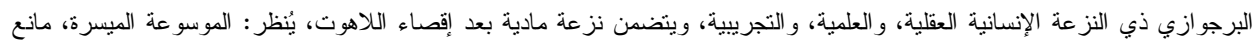

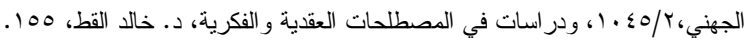

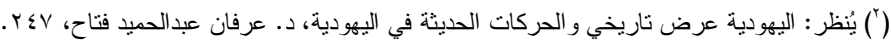
(")التحرير ، ظهر هذا المصطلح في ألمانيا في القرن السابع عشر والثامن عشر مصاحباً النهضة الأوربية، ويُقصد به الاتجاه الذي يتركز

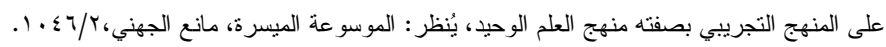

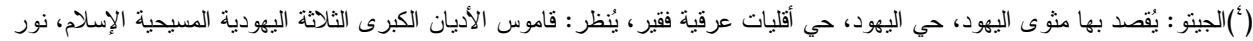

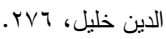
(") يُنظر : الملل المعاصرة في الدين اليهودي، إبماعيل الفاروقي، 19. 19.

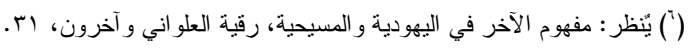

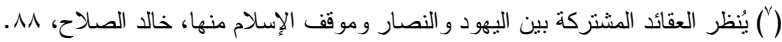


هذا التغيير وفحو اه، فجاء قسم أرثوذكسي وعبّر عن خوفه من ضياع الدين تحت وطأة

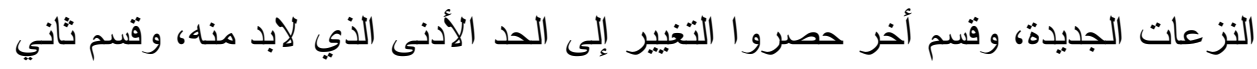

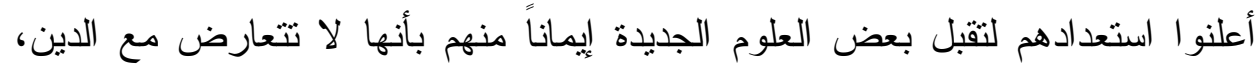

وفي حال التعارض يأخذون بالدين ('). فأصبح هناك بون شاسع بين الطائفتين، فكان لابد من أن يوجد طائفة تتوسط

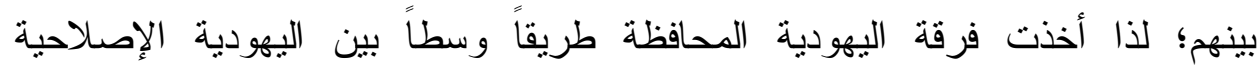
و اليهودية الأرثوذكسية،فنشأت في أواخر القرن التاسع عثر و أو ائل القرن العثرين هذه لئه الفرقة؛ أعني فرقة اليهودية المحافظة وذللك في الولايات المتحدة، وأصبحت من ألهر أهم و أكبر الحركات الدينية اليهودية الحديثة في العالم (؟). و اتفق مؤسسو اليهودية المحافظة مع الإصلاحيين على أن تاريخ الديانة اليهودية كله كان تاريخ التغيير والتطور، فلابد أن تستجيب ديانتهم بشكل كبير الإني للتحديات التاريخية، لكنهم اختلفو المع الإصلاحيين المتطرفين حول المدى المسموح به لتحديث

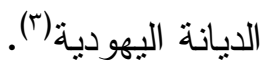

ويمكننا القول وبناء على ما سبق إن اليهودية المحافظة ظهرت لسببين:

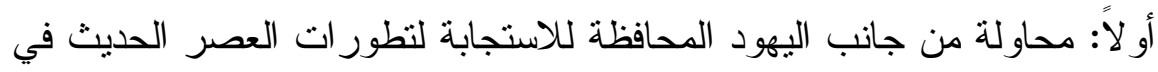
العالم الجديد، وتغيير اته. ثانياً: رد فعل لليهودية الإصلاحية أكثر من كونها رد فعل لليهودية الأرثوذكسية؛

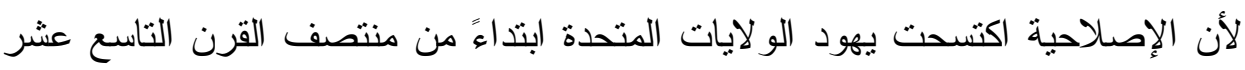

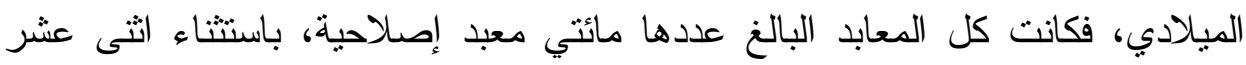

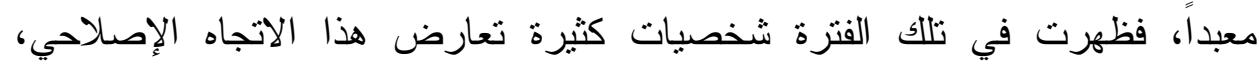
خصوصاً في صيغته المتطرفة، وتهاجم أعلامهم، مثل ألكسندر كوهوت فئرة الذي هاجم

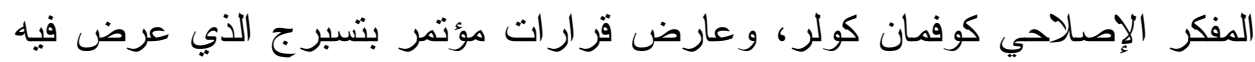

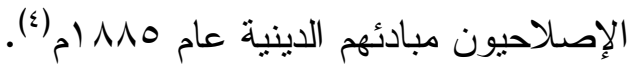

(') يُنظر : الملل المعاصرة في الدين اليهودي، إنماعيل الفاروقي، .9.

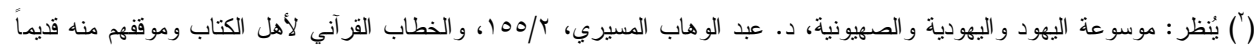


كما قام فر انكل الذي لم تعجبه الإصلاحات الثاملة للحياة بإجر اء تعديلات في

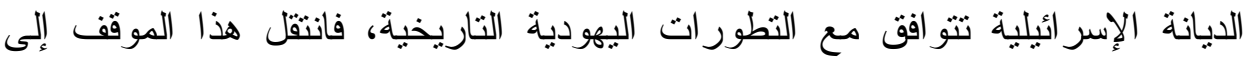

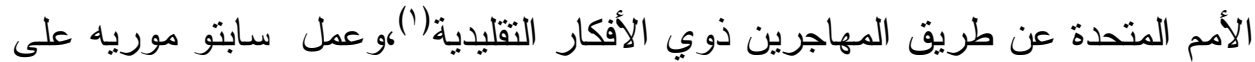

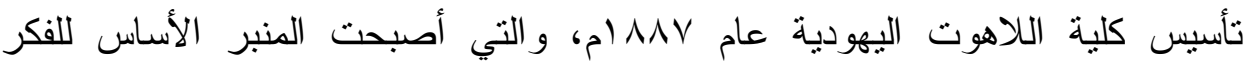

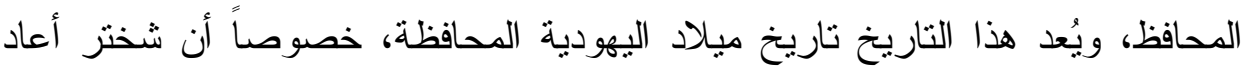

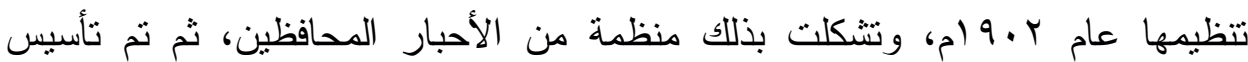
جمعية الحاخامات الأمريكية، وبذلك أصبحت هذه الجمعية مع معهد أمريكا الموحد الذي أنشأ عام باه (9 (م، وكلية اللاهوت اليهودية أهم عناصر الهيكل التنظيمي لليهودية

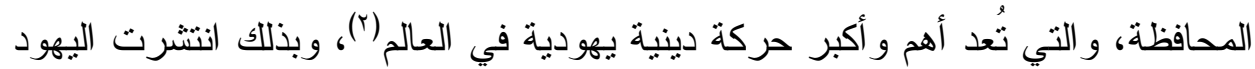
المحافظة حتى أصبحت أكبر اتحاد رسمي لليهود يتجاوز كلاً من الإصلاح و اليهودية

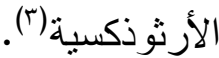

ويمكننا القول أيضاً إن الأسباب التي ظهرت فيها اليهودية المحافظة، تمخض أنها عنها وجود أهداف رئيسة لهذه الفرقة، هي (๕) الفول: أولاً: تتمية الثعور بالوحدة الجامعة لبني إسر ائيل، وقد أطلق عليه أهم مفكرين هذه الفرقة سولومون شختر بالكاثوليكية (أي الدين الجامع).

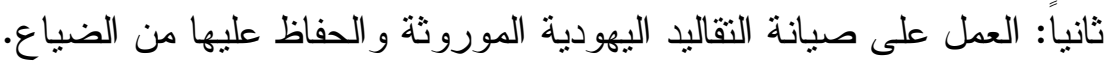
ثالثاً: تنمية الدر اسات و المعارف الئسية اليهودية وتطوير ها. المطلب الثاني: أبرز أعلام فرقة اليهود المحافظة وأماكن انتشارهم

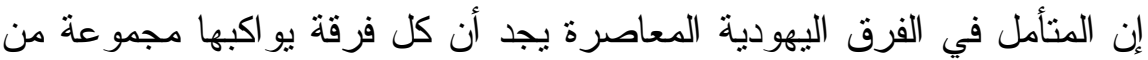
المفكرين و الأعلام الذين يدعمونها، ويتبنون أفكار ها، ويحملون لواء الدفاع عنها، وقد تكون معتقداتهم هي الجذور التي بُنيت عليها اتجاهات هذه الفرقة، ومن ذللك فرقة اليهود المحافظة،ولعل في هذا المطلب ألقي الضوء على أبرز أعلام ومفكري هذه هذه هنه الفرقة، و أماكن انتشار ها: 


\section{أولاً: أبرز أعلام فرقة اليهود المحافظة:}

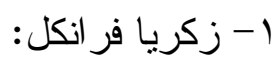

هو عالم ديني يهودي، كان من أقطاب ما يُسمى (علم اليهودية)، وتعود إليه

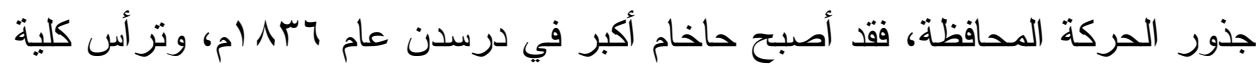
لاهوتية في برسلو عام \مامه، وقد حاول مزج القيم اليهودية التقليدية بالمعرفة

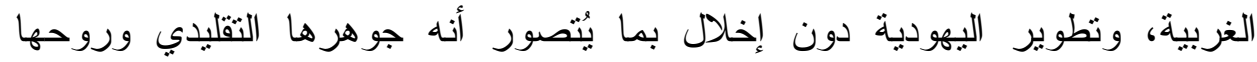

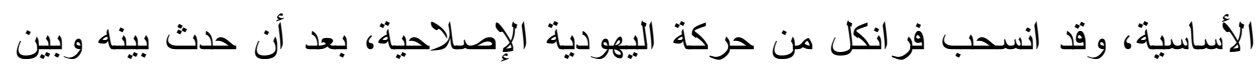

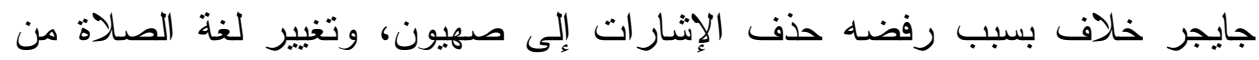
العبرية إلى لغة الوطن الذي يُعاش فيه، وقد كان يعيش في ألمانيا('). حاول فر انكل تعريف الموقف المتوسط، فألقى و عظه في الكنيسة باللغة الألمانية، وقال مؤنباً الأرثوذكس: "يجب علينا أن نوقن أنه في منهاج الملة الأرثوذكسية الذي في فئي

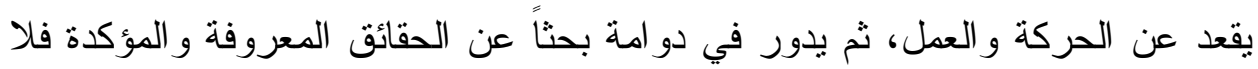

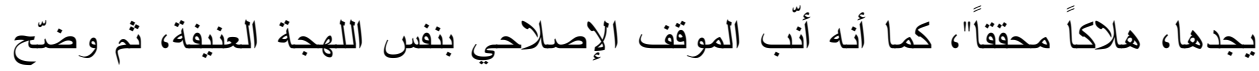

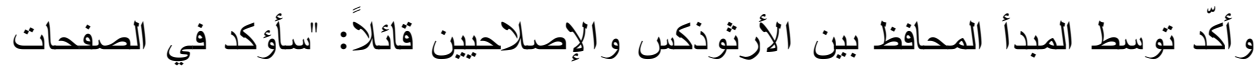

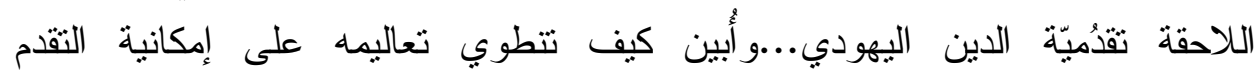
العصري...أما كيف لهذا التقدم أن يستمر الآن فذلك يجب أن يتعين بالبحث العلمي

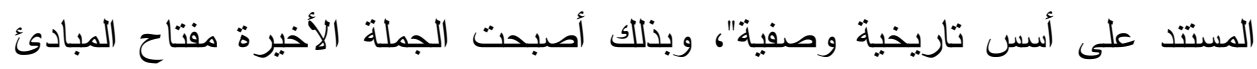
المحافظة، وركيزة الملة برمنها (؟). و على ضوء ما سبق اسنطاعت اليهود المحافظة أن تتمو، و أن يتكاثز أعو انها بسرعة، و أن تصبح قوة رئيسية منطورة، ذات أثر كبير في الحياة الروحية و التقاليد

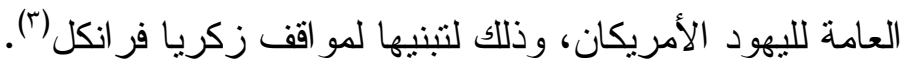

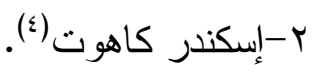

و هو حاخام كنيس في نيويورك، عارض الكثير من أفكار اليهودية الإصلاحية، ويرى أنه لابد أن يحدث تغيير وتظور إيجابي بدون أن يؤدي ذلك إلى تدهور أو تمييع 
الدين اليهودي، فقال موجهاً كلامه ضد زعيم الإصلاحيين كارفمان كوهلر : "الإصدلاح الذي يبغى التقدم بلون موافقة السلطة الموسمية الربانية اعوجاج، وهو هيكل أو إو جثة

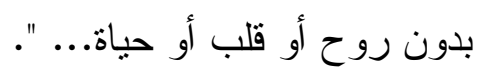

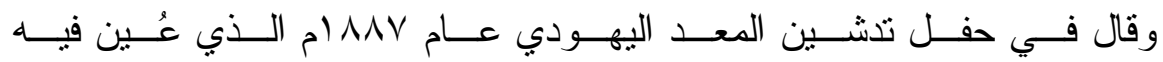

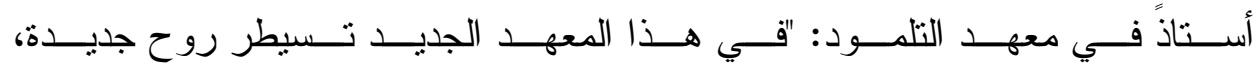

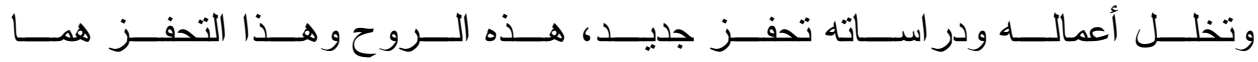

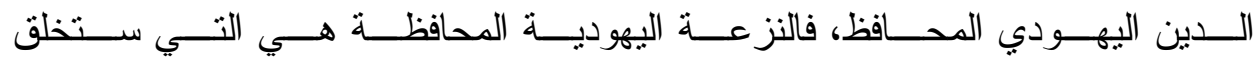

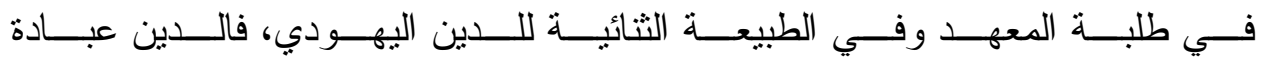

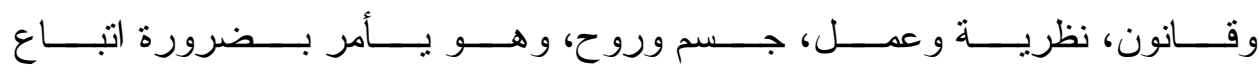

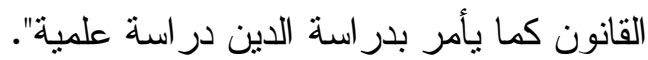

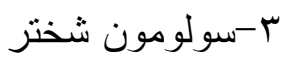

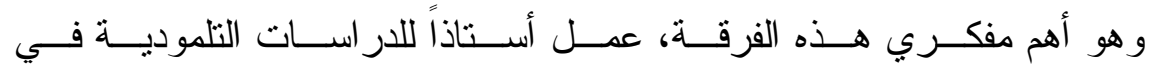

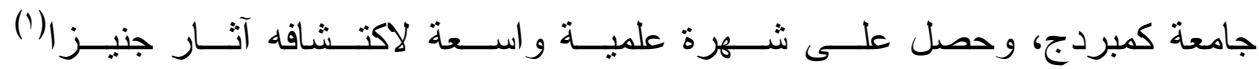

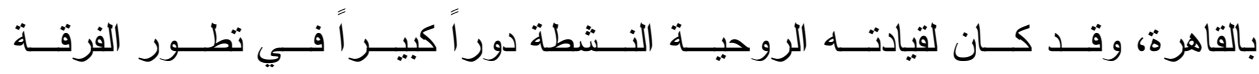
المحافظة و انتشار ها (r).

ويُعد شختر مسئولاً أكثر من أب شخص عن إدخال الأفكار الصهيونية على

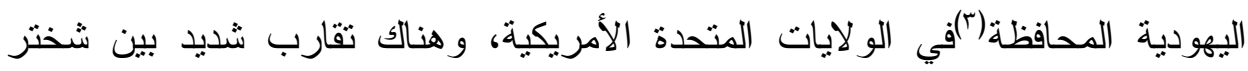
ومارتن بوبر لكل من التاريخ والوحي رغم اختلاف المصطلحات الدينية و الفلسفية

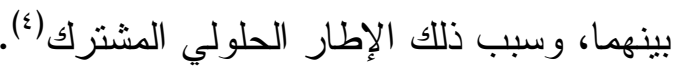
وقد بين الدكتور المسيري المقصود بالعقيدة الحلولية لدى اليهود حيث قال:

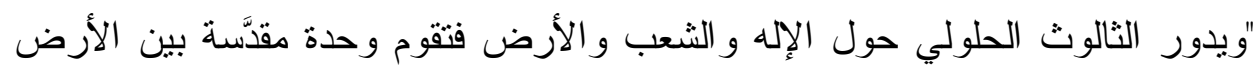

(') الجنيز ا: يُقصد بالجنيز ا بشكل عام تلك الأور اق و الوثائق اليهودية التي لا يجوز إحر اقها أو إهمالها حسب الثريعة اليهودية؛ وذلك لذكر

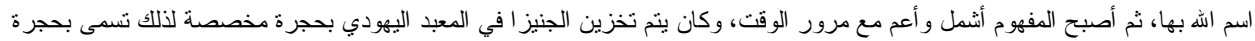

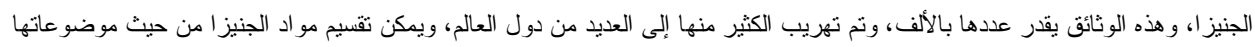

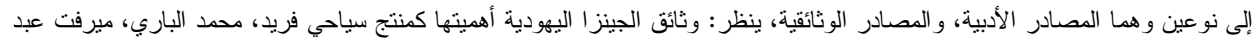


و الثعب لحلول الإله فيهما وتوحده معهما، ولذا ترتبط الديانات و العبادات الوثثية

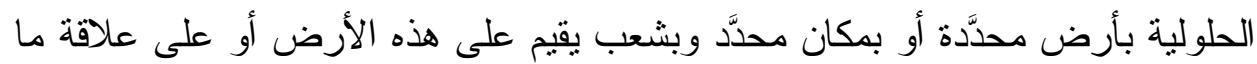

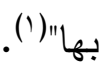
ثانياً: أماكن انتشار اليهود المحافظة:

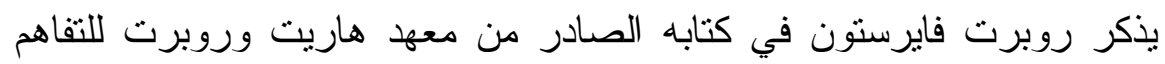

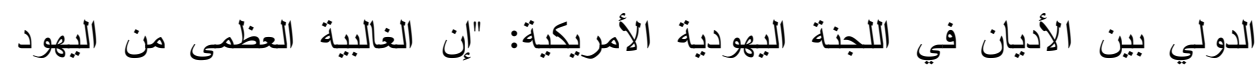

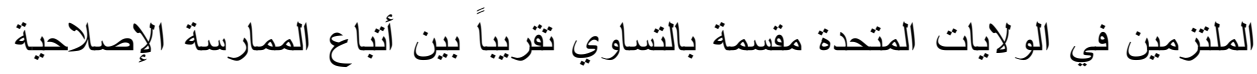

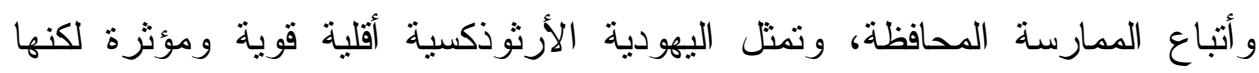

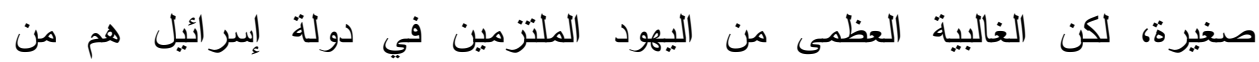

الأرثوذكس؛ ويشكل المحافظون و الإصلاحيون أقلية صغيرة جداً لكنها متتامية"(r). وقد نز ايد عدد اليهود المحافظين في أنحاء العالم، وخصوصاً في أمريكا

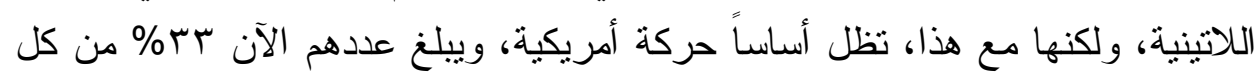

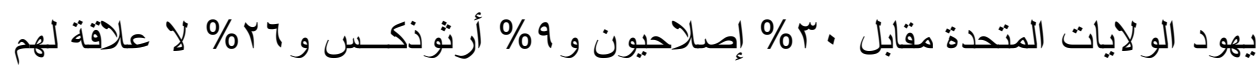
بأية فرقة دينية(ז).

كما يذكر روبرت "أن نصف سكان الولايات المتحدة تقريباً من اليهود لا لانيات

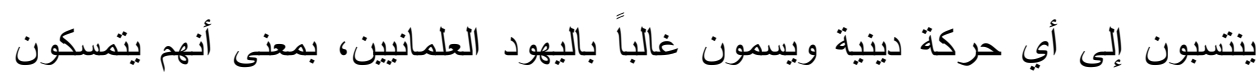

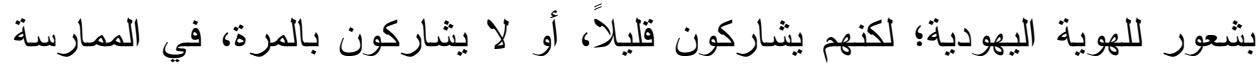

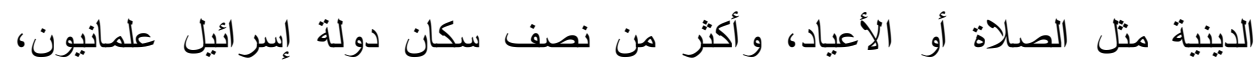

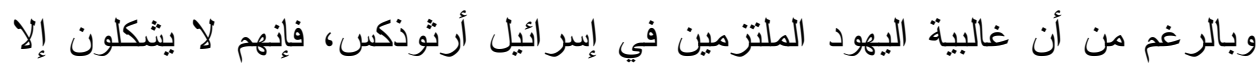

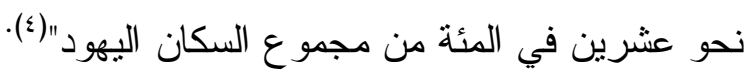
المطلب الثالث: الفكر الديني لاى فرقة اليهود المحافظة وأبرز عقائدهم من خلال تتبع الفكر الديني بشكل عام في اليهودية المحافظة نلاحظ أنه لا يمكننا

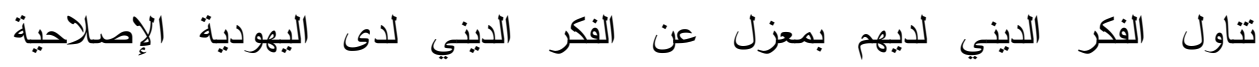
و الأرثوذكسية، خاصة وأن اليهودية المحافظة ظهرت كرد فعل لليهودية الإصلاحية؛

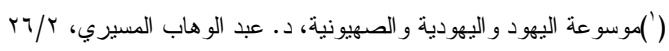

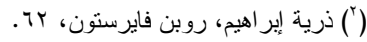

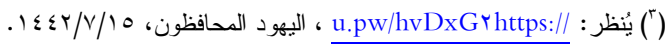

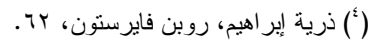


لذا نجد أن المحافظة احتفظت بمفهوم الهالاخا('اعلى عكس الحركة الإصلاحية، وتختلف عن الأرثوذكسية في أنها نرى أن الهالاخا تتغير من جيل إلى جيل، وتتأثر

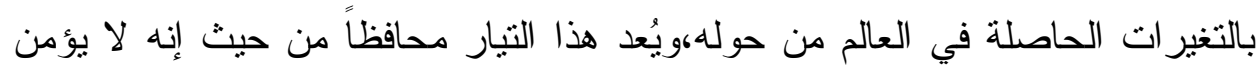
بتغييرات جذرية منل التيار الإصلاحي، ولكنه يؤمن بالتغيير و التطور بقيادة حاخامات تؤمن بالتغيير التدريجي (؟).

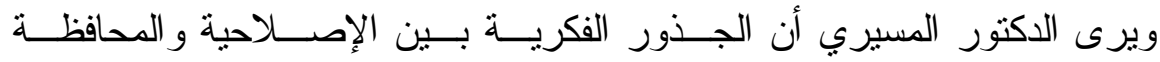

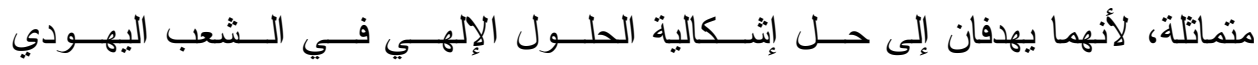

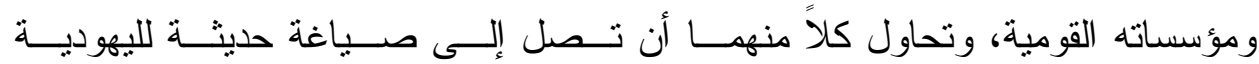

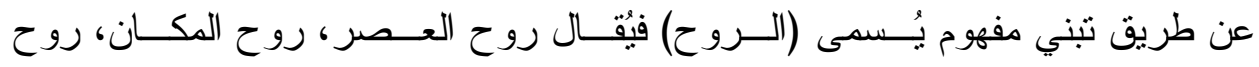

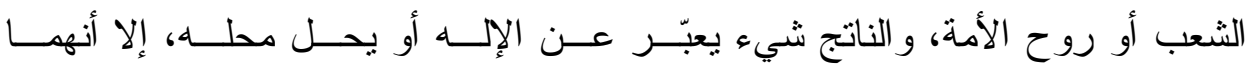

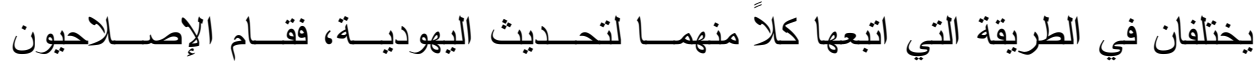

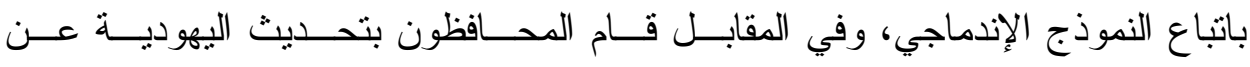

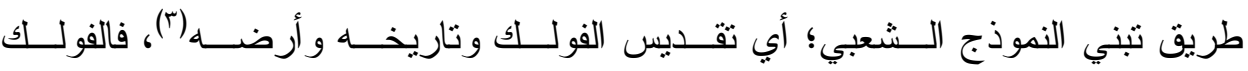

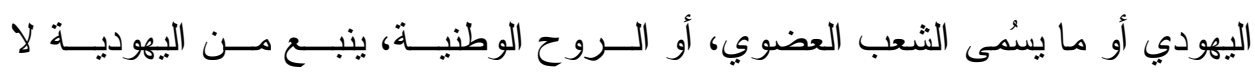

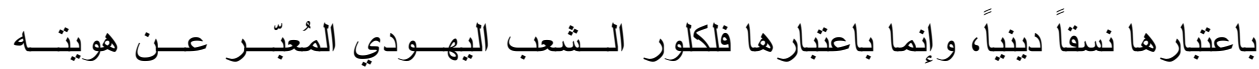

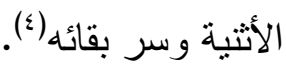
أما بالنسبة للأرثوذكس فهناك تشابه بنيوي كبير جداً بينهم وبين المحافظة؛

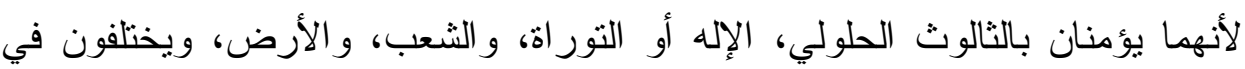
تأكيد أحد عناصر الثالوث الحلولي على حساب الآخر .

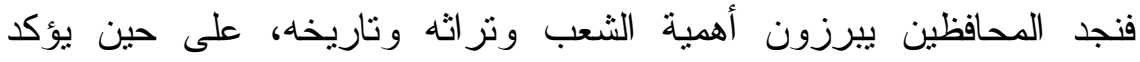
الأرثوذكس أهمية الوحي الإلهي و التور اة، ويضفي كلا الفريقين هالة من القداسة على ولى ونى

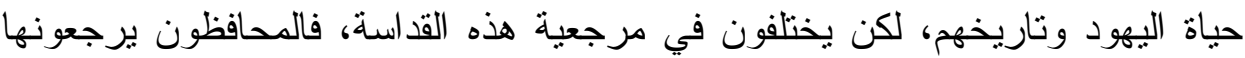

(') هالاخا: ويُقال هالاثنا، هي مجموعة من المواد التثريعية غير المنصوص عليها مباشرة في الشريعة الموسوية، وهي تشثكل أغلب

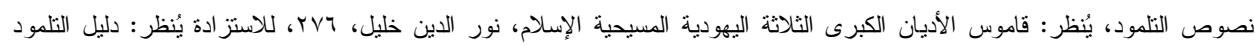

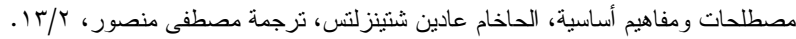

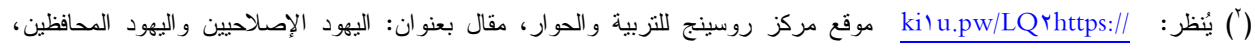


إلىى أصول قومية أو إلى روح الشعب، أما الأرثوذكس يرجعون القداسة إلى أصول

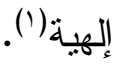

استتاداً لما سبق يمكننا أن نُبرز أهم عقائد و أفكار اليهود المحافظة في النقاط التالية:

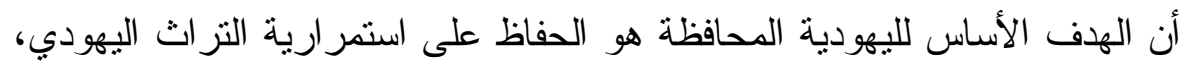

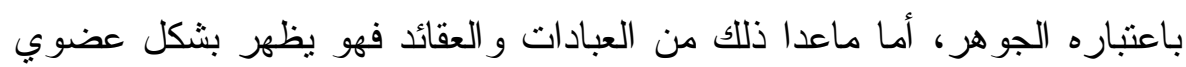

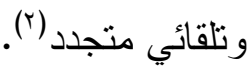

يؤمن المحافظون بمقولة الوحدة في التنوع، أي الإبقاء على تتوع الفكر الديني

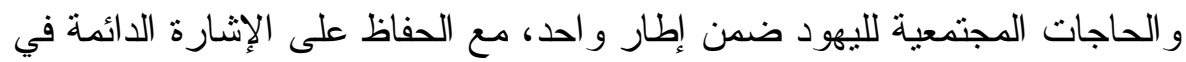
جميع الطقوس إلى تاريخ إسر ائيل الماضي و إلى عودتهم إلى وطنهم، و إعادة بناء

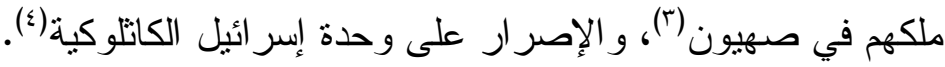
يعتقد المحافظون بضرورة المحافظة على المقومات اليهودية من خلص الالنزام

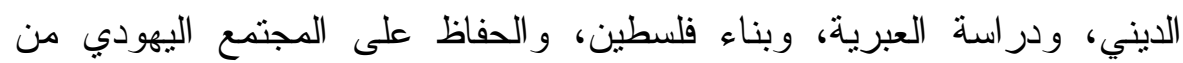
الاندماج و الذوبان مع المجتمعات الأخرى (ه). يعتقد المحافظون أن التلمود نتاج ثقافي لابد الاستفادة من قيمته العامة في المواقف الأف

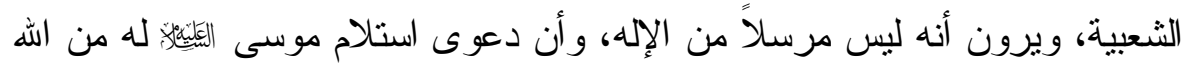

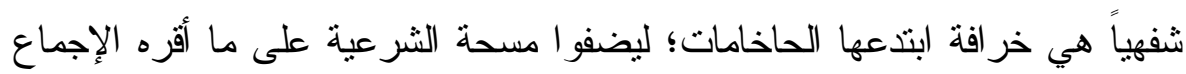

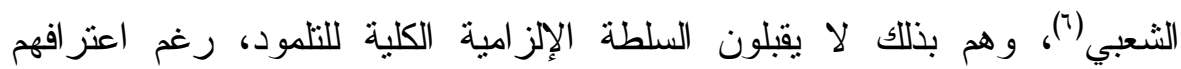

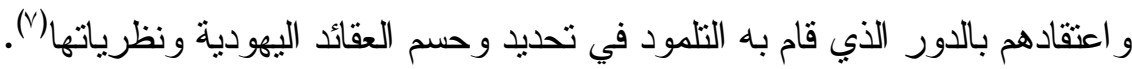

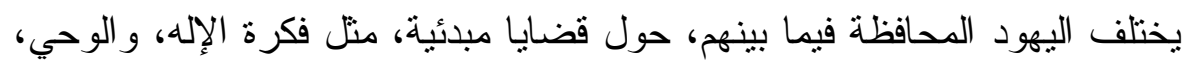
ويعتقدون بأن الشعب اليهودي قد تتطور عبر تاريخه، فاليهودية ليست مجموعة

من العقائد الثابتة، إنما تر اث يتطور بشكل مستمر (^).

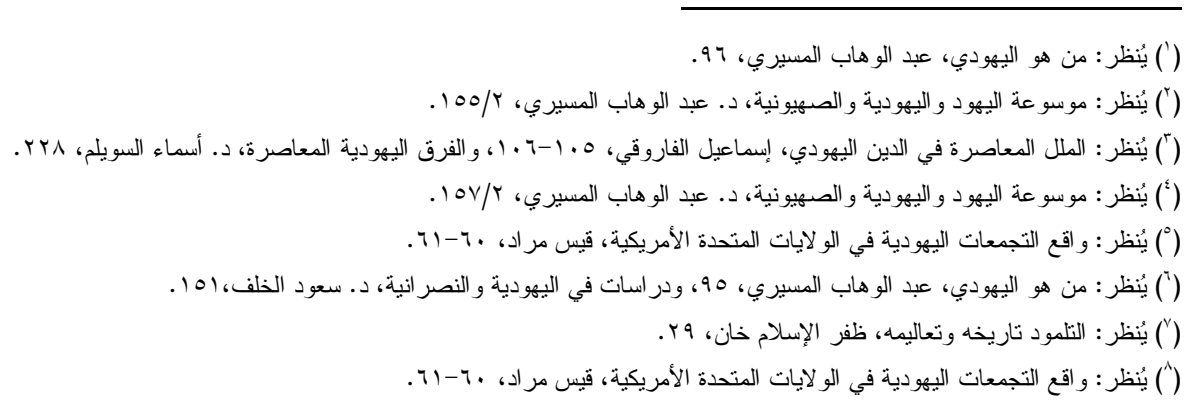


يؤمنون بأن الوعظ و الصلوات لابد أن تُقام باللغة التي يفهمها العابدون، و لا يجب

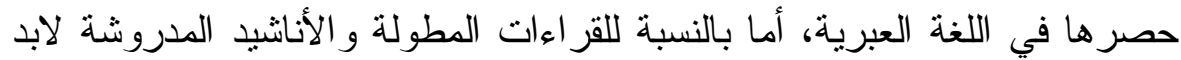
من حذفها، حتى تتسم الصلاة بالهدو ء و الرز انة(').

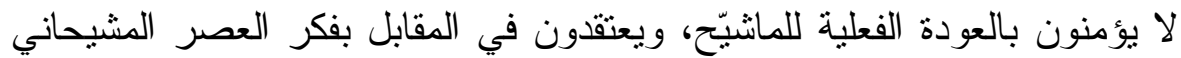

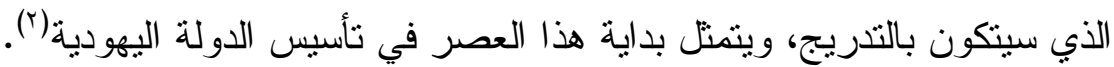

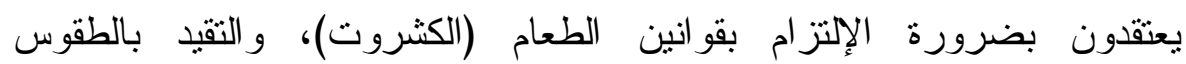

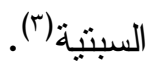
يعثقون بضرورة تربية النساء تربية دينية وإثراكهن في أعمال الكنيسة

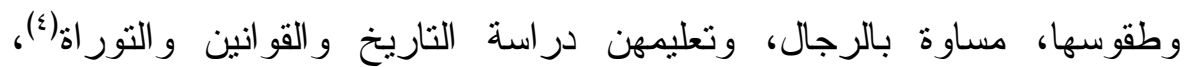

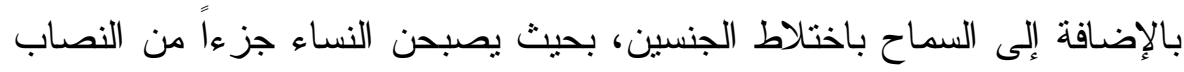

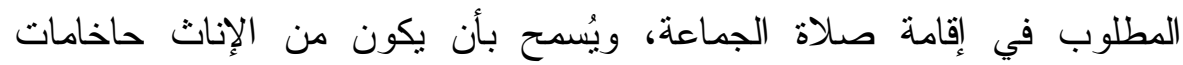

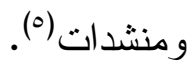

ويُلاحظ بشكل عام أن التشابه بين بعض الثعائر في اليهودية المحافظة

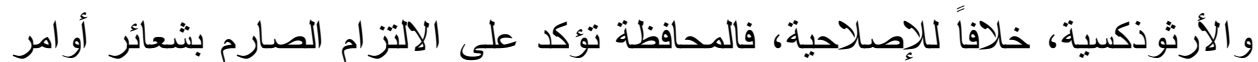

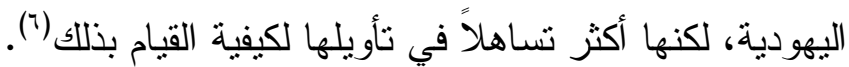

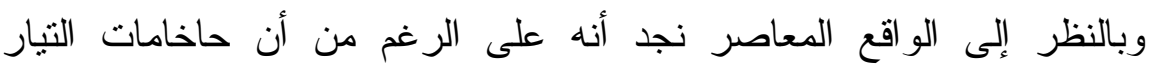

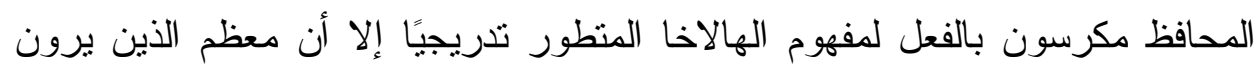

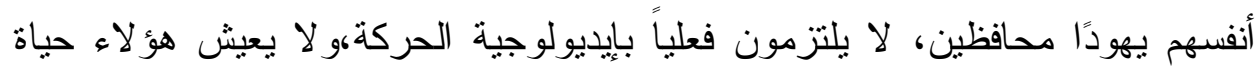

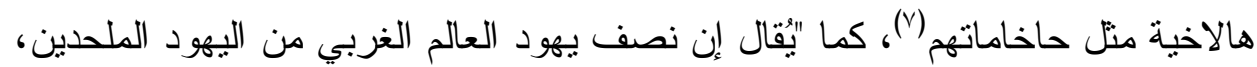
أما النصف الآخر فغالبيته الساحقة من الإصلاحيين و المحافظين و التجديدين، و لا يشكل

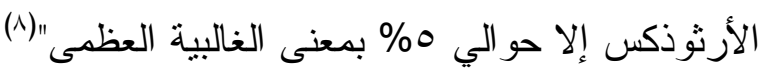


كما يتضح أن بعض شعائر اليهودية المحافظة منحت المساواة للمر أة، مثل اليهودية الإصلاحية، على الرغم من اختلاف طبيعة وفهم هذه المساو اة من مكان إلى لى لى لئر

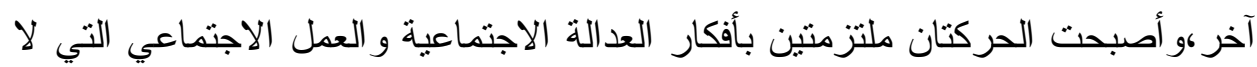
تستهدف اليهود وحدهم،حيث أخذتا أفكار العدالة الثاملة، الموجودة في التقاليد اليهودية، ونقلوها إلى مكان مركزي في فهمه لليهودية بطريقة مرفوضة من قبل اليهودية الأرثوذكسي (1).

ويمكننا القول إجمالا - مع بعض الاستثناءات - بأنه وجد كل من التيار الإصلاحي و التيار المحافظ بالإضافة إلى تيار ات أخرى أصغر غير أرثوذكسية طريقه للمو ازنة بين جو انب خاصة وأخرى عامة داخلية وأخرى خارجية دن التقاليد اليهودية التي تكمل بنظر هم بعضها البعض، ركزت اليهودية الأرثوذكسية على جو انب معينة من التقاليد اليهودية الداخلية(؟).

\section{المطلب الر ابع: علاقة اليهود المحافظة بالصهيونية و إسر ائيل}

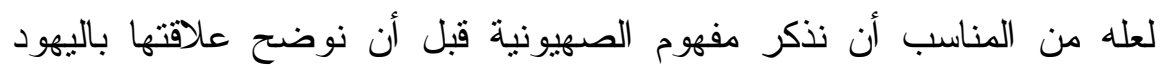

$$
\text { المحافظة حتى يتبين بعمق مدى هذه العلاقة و أبعادها. }
$$

"الصهيونية هي حركة سياسية عنصرية منطرفة، ترمي إلى إقامة دولة لليهود

في فلسطين تحكم من خلالها العالم كله"("). و اثتقت الصهيونية من جبل صهيون "الذي يقع في الجنوب من بيت المقدس، وقد اقتحمه داوود إبان ملكه، واستولى عليه من اليبوسيين الذين كانو ا يقطنونه (وأخذ

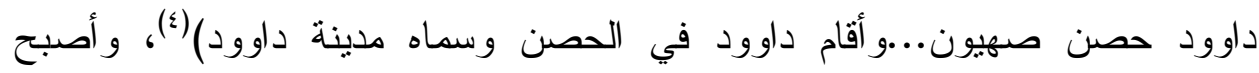

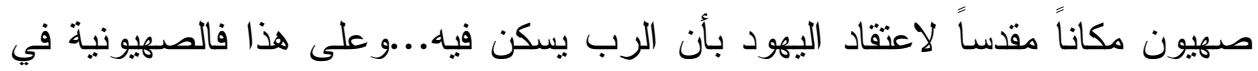
أبسط تعاريفها هي استقر ار بني إسر ائيل في فلسطين أي جبل صهيون ومان لاعن حوله"(ه).

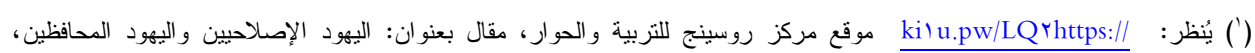
$1 \leq \leqslant Y / \mathrm{V} / 10$

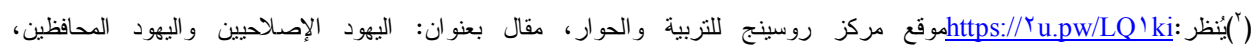
. $1 \leqslant \leqslant r / v / 10$ (") الموسو عة الميسرة في الأديان و المذاهب و الأحز اب المعاصرة، مانع الجهني،

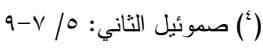

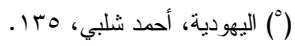


وهناك علاقة وثيقة تربط بين الصهيونية واليهود المحافظة؛ تظهر في عدة

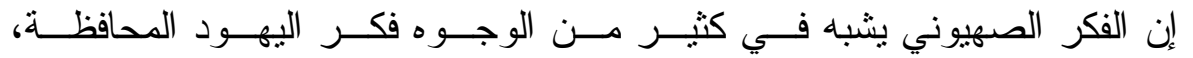

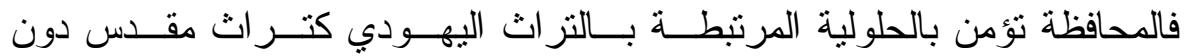

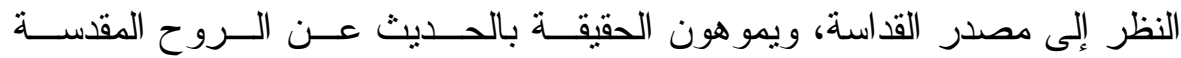

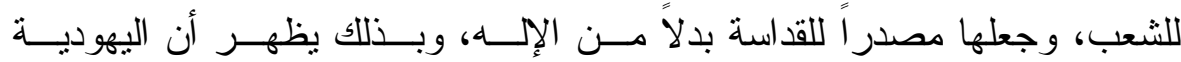

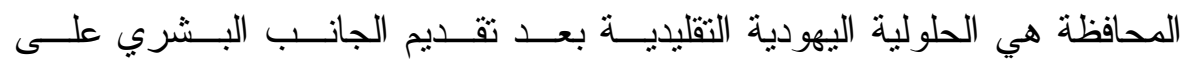
الجانب الإلهي، وهذا هو جوهر الصرهيونية(').

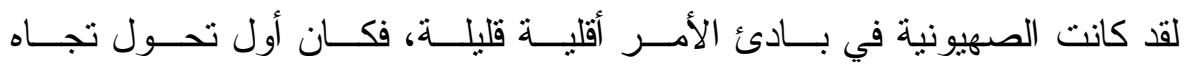
الصهيونية، هو الذي قام به المحافظون، فقد تبنــى المحــافظون كـلـل البرنــامج

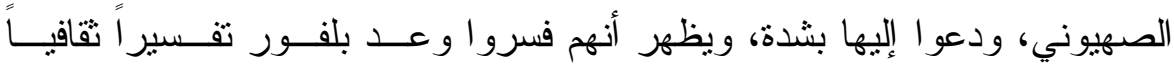

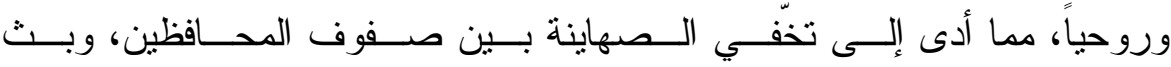

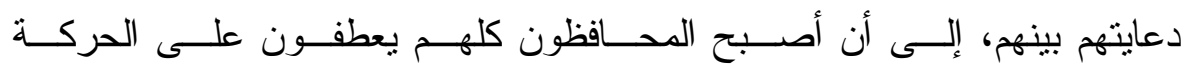

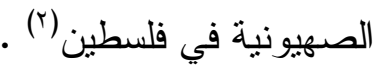

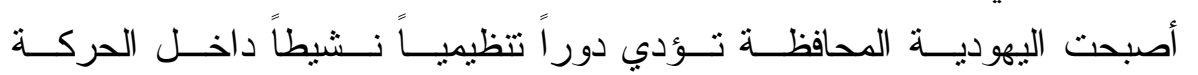
الصهيونية، فقامت بتأسيس منظمة مركــاز وهـــي حركــة تهـدف إلــى إعــادة تأكيد الصهيونية المحافظة(")

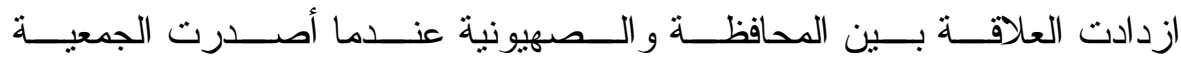

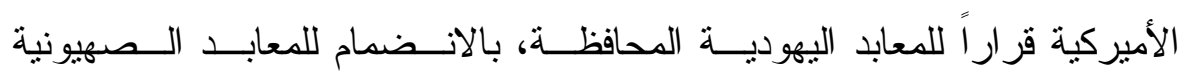
العالمية بشكل جماعي (๕).

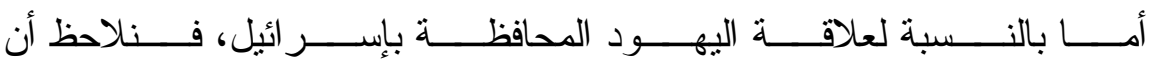

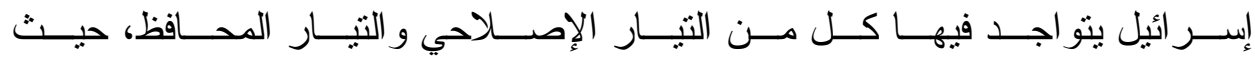

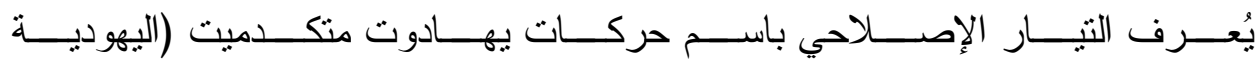

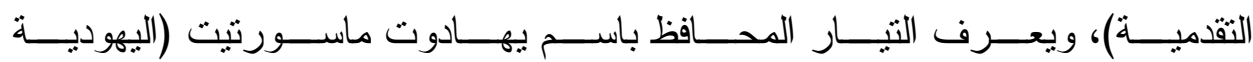




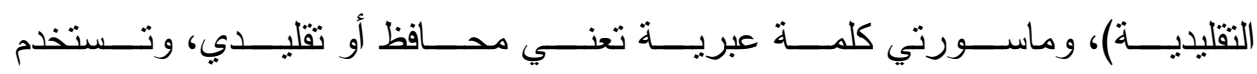
للمحافظين خاصة في إسر ائيل (1). وقد تطورت الحركتان في إسر ائيل نتيجة لهجرة اليهود الذين جاءوا من الجاليات الإصلاحية و المحافظة في الخارج،كما نجحت الهيئات و الكنس الإصلاحية و المحافظة

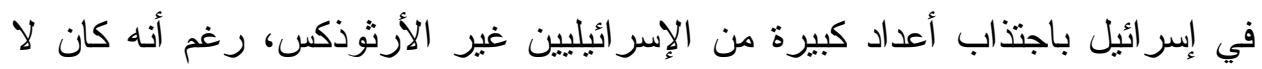

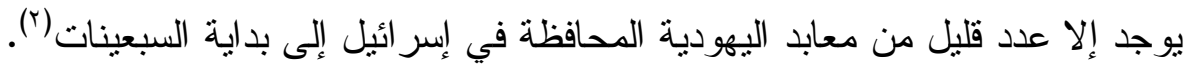

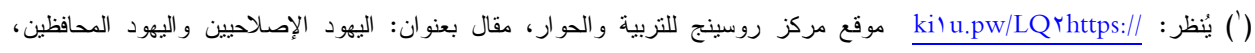
آ

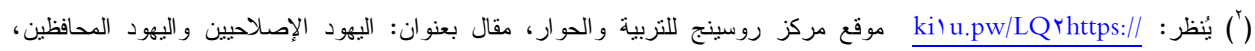


المبحث الثاني: عقيدة أرض الميعاد لاى فرقة اليهود المحافظة والموقف منها المطلب الأول:مفهوم أرض الميعاد عند اليهود المئد

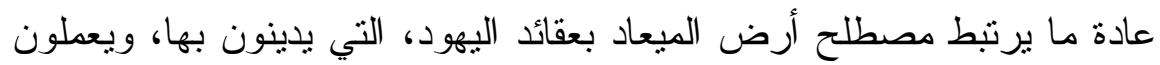
من أجلها، ويستدلون على حقهم فيها بنصوصهم المقدة، ولعله من المناسب أولاً توضيح المقصود بأرض الميعاد ثم مناقثة معتقد اليهود فيها. المقصود بأرض المبعاد:

أرض الميعاد هي أرض كنعان كما كانت تسمى سابقاً، ويُقصد بأرض كنعان

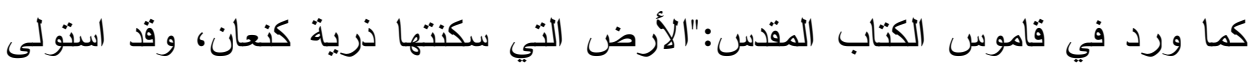

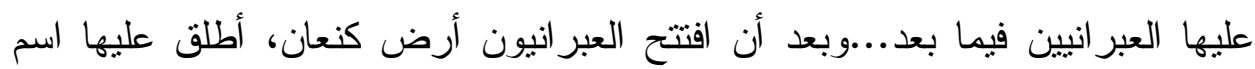

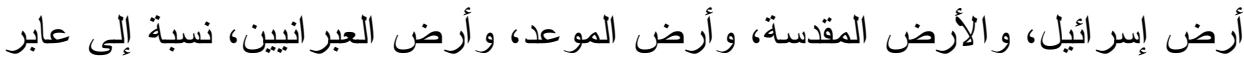
أحد اجداد إبر اهيم، اما اسم فلسطين فقط كان بطلق في الأصل على الساحل الذي كان

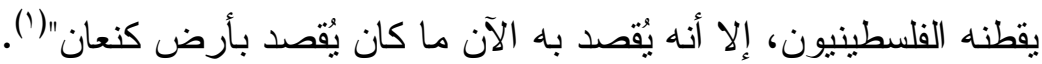

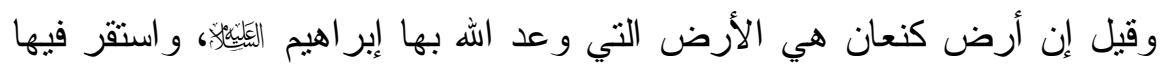

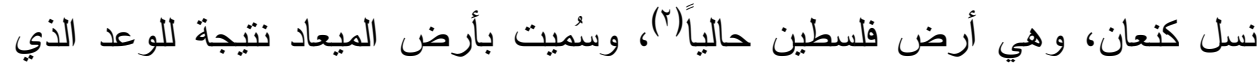

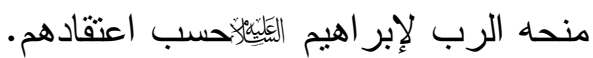

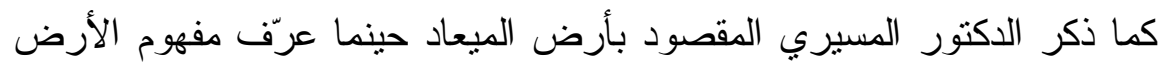

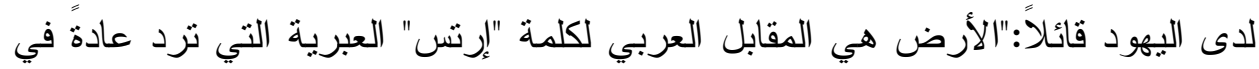

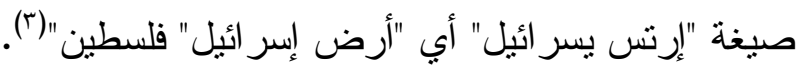

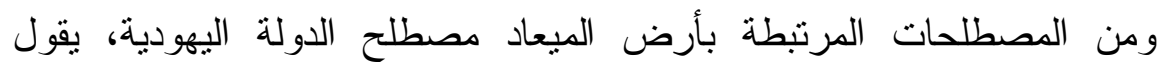
إسرائيل شاحاك(غأفي توضيح الجوانب المرتبط بهذا المصطلح :" لا يمكننا أن نفهم

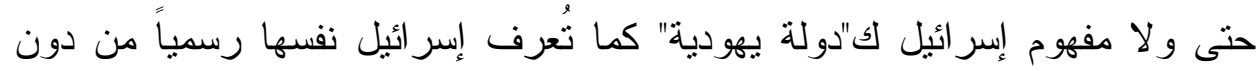
بحث المو اقف اليهودية السائدة تجاه غير اليهود، و التصور الخاطئ الثائع بأن إسر ائيل

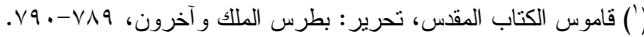

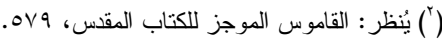

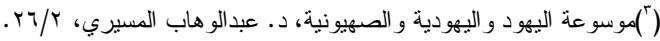

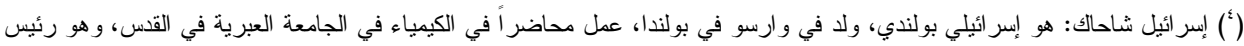

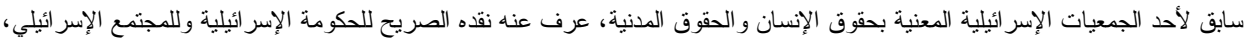

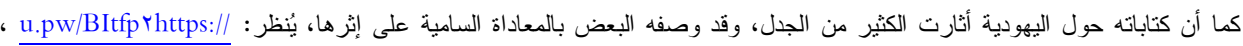


ديمقر اطية حقيقية، حتى من دون أن نر اعي حكمها في المناطق المحتلة، هو تصور ناشئ عن رفض مو اجهة المغزى في مصطلح "الدولة اليهودية" بالنسبة لغير اليهود" (').

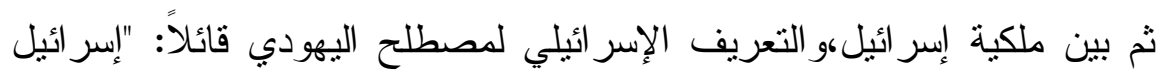

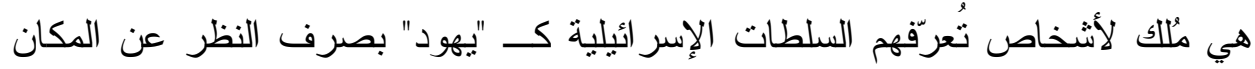

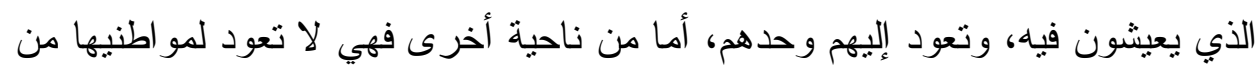

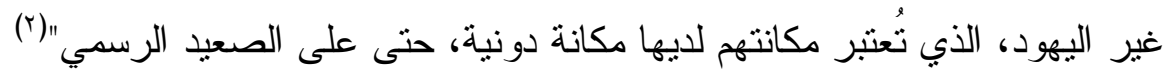

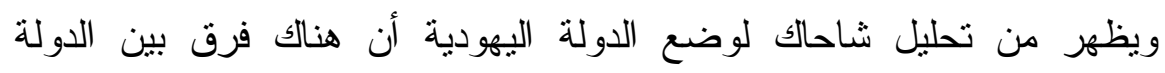

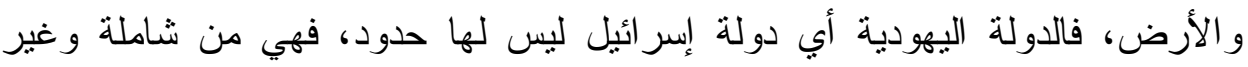

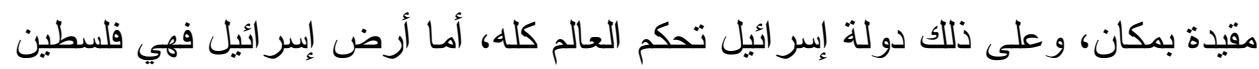
و التي من خلالها تحكم العالم (r).

المطلب الثاني: معتقد اليهود في أرض الميعاد من خلال كتبهم وأقوالهه يعثقد كثير من طو ائف اليهود، ومن ضدنهم فرقة اليهود المحافظة بالو عد الإلهي

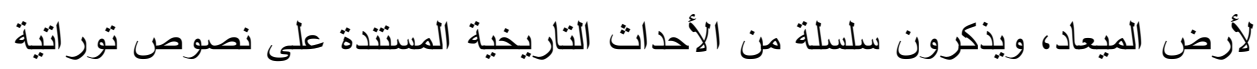

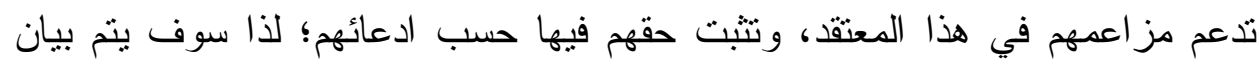
معتقدهم في أرض الميعاد، من خلال نصوصهم المقدسة و أقو الهم في ذلكا: أولاً: معتقد اليهود في أرض الميعاد من خلاد نصوصن خصهم المقدسة:

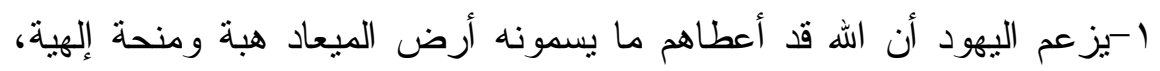

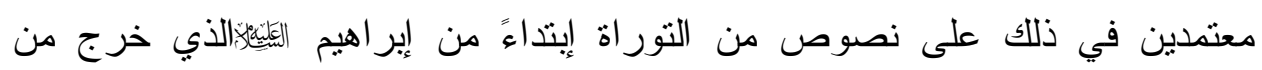

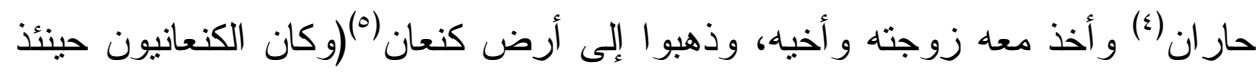

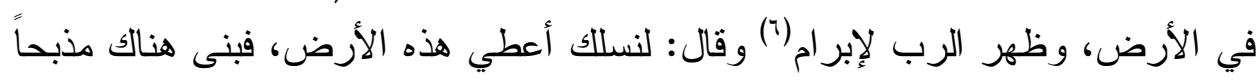
للرب الذي ظهر له) (v).

(') (') الديانات اليهودية وتاريخ اليهود، إسر ائيل شاحاك، 19 (')

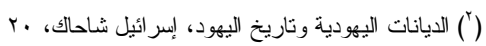

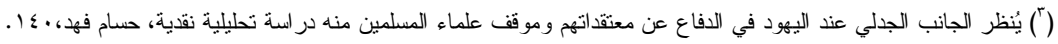

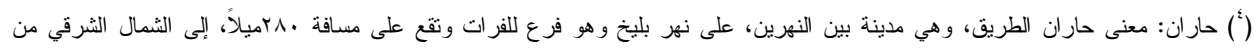

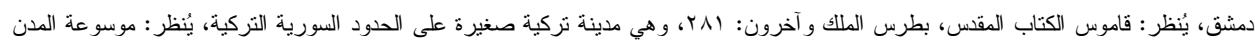

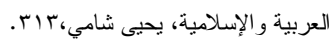

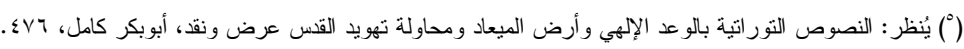

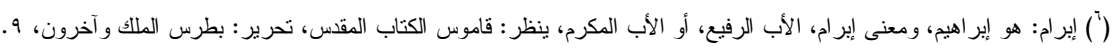

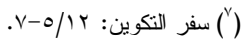




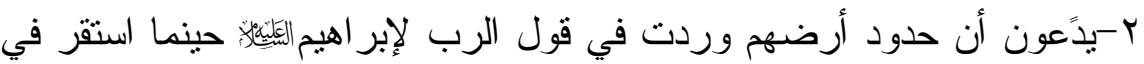

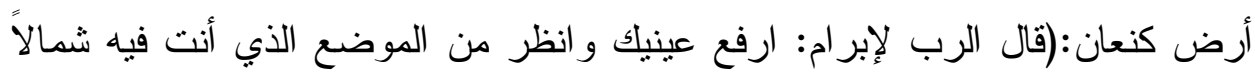

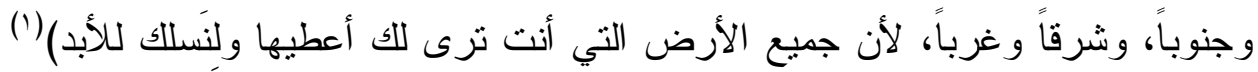

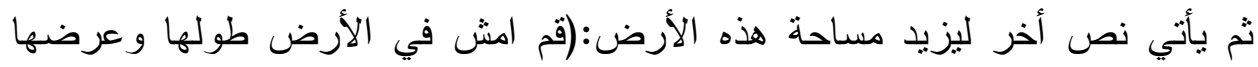

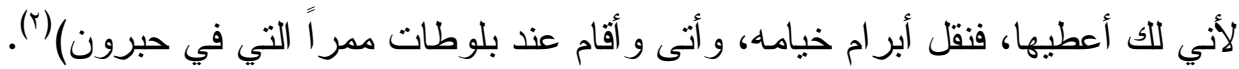

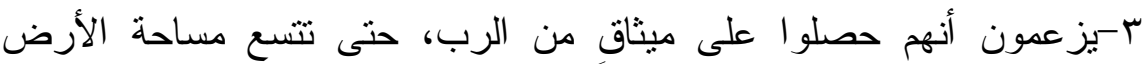

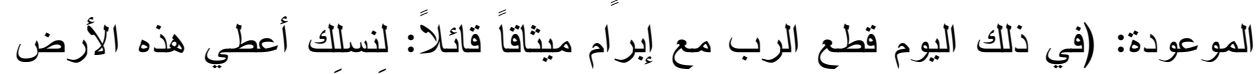

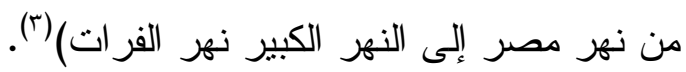
ع-بعتقد اليهود أن أرضهم ودولتهم الموعودة لابد أن تشمل كل البقاع: (هذه

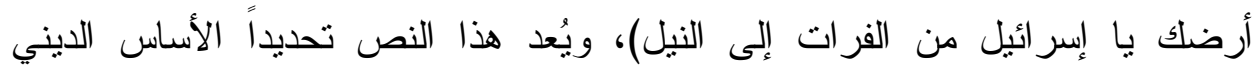

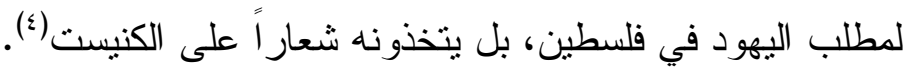

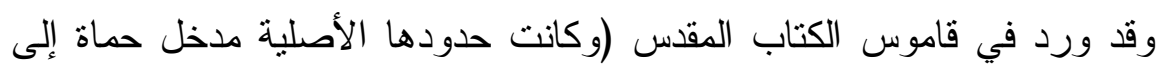
الثمال وبادية سوريا و العرب إلى الثرق وبادية العرب إلى الجنوب وساحل البحر المنوسط إلى الغرب)(م).

ه-يعتقد اليهود أن اله منحهم الأرض ملكاً أبدياً؛ لإبادة البشر ليس لدعوتهم

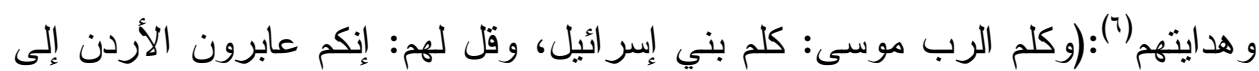

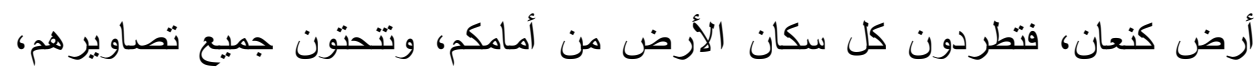

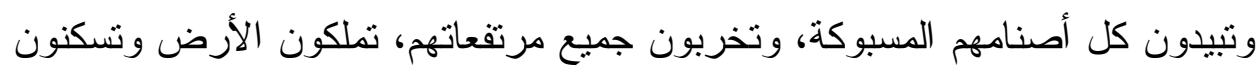
فيها؛ لأني قد أعطيتكم الأرض لكي تملكو ها) (v).

$$
\begin{aligned}
& \text { (') سفر التكوين: rا/ (1) ا-10. }
\end{aligned}
$$

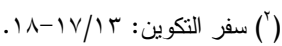

$$
\begin{aligned}
& \text { (") سفر النكوين: 1N/10. }
\end{aligned}
$$


7-ويستمر التسلسل التاريخي لمعتقده من إبر اهيم عليه السلام ثم بقية الأنبياء،

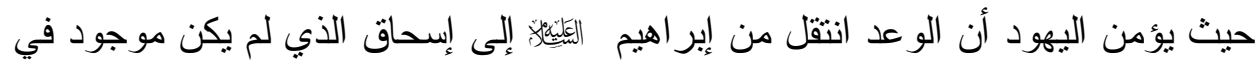

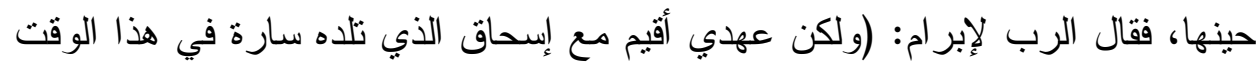

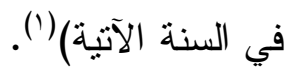

V يغترب اليهود، ويلجؤون للذهاب إلى مصر بسبب الجوع، فيُستعبدون فيها

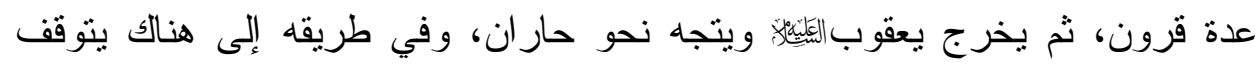

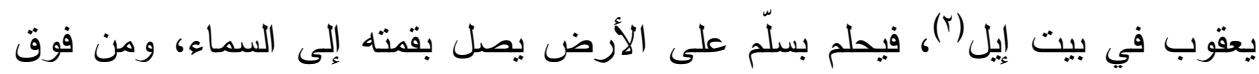

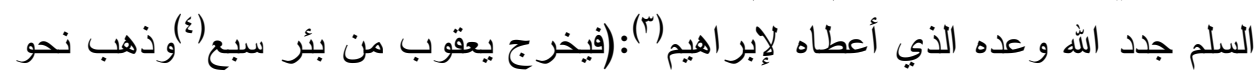

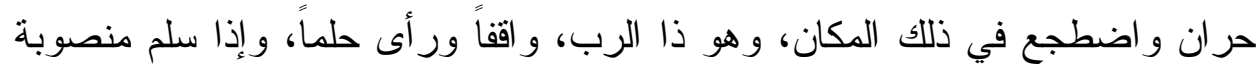

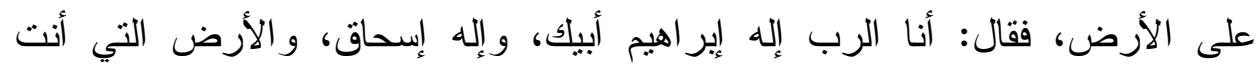

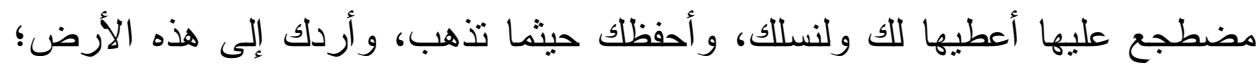

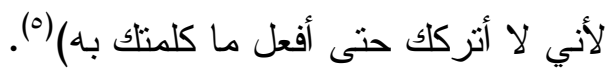

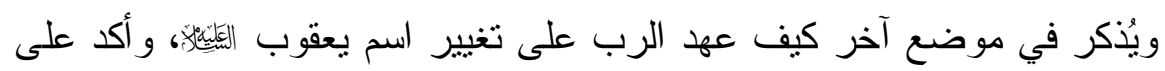

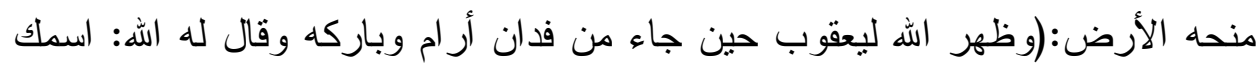

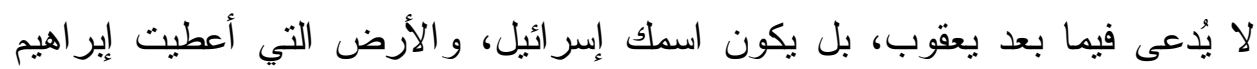

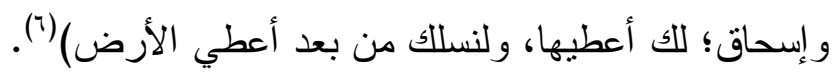

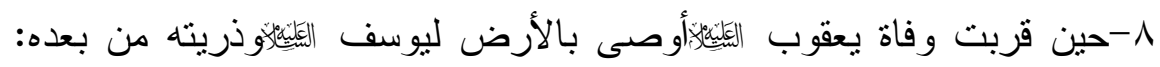
(وقال يعقوب ليوسف: الله القادر على كل شيء ظهر لي في لوز أرض أرض كنعان

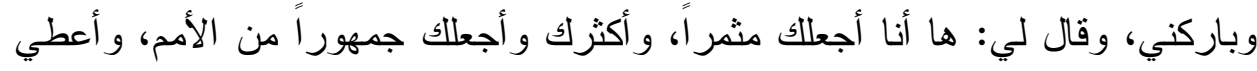
نسلك في هذه الأرض من بعك ملكاً أبدياً) (v).

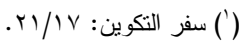
(') بيت إيل: اسم عبري معناه بيت اله أول ما قدم أرض الميعاد، نصب خيمته في الأراضي المرتفعة قرب بيت إيل، يُنظر : قاموس الكتاب المقس، بطرس الملك و آخرون، ... ب.

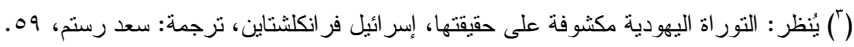

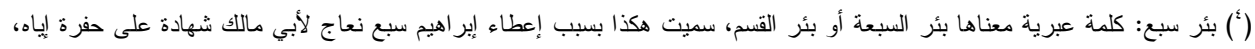

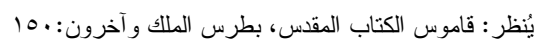

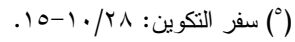

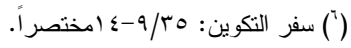

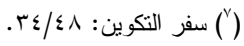


9- جدد يوسف الئلئهن الوصية بالوعد الإلهي إلى أبنائه:( وسكن يوسف في مصر هو بيت أبيه، وقال يوسف لإخوته: أنا أموت، ولكن الله سيفتقدك، فيصعدكم من هذه الأرض التي حلف لإبر اهيم و إسحاق ويعقوب، واستحلف يوسف بني إسر ائيل قائلاً:

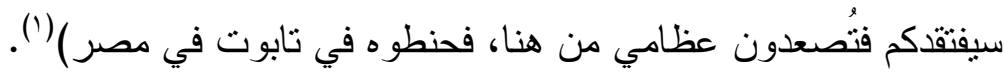

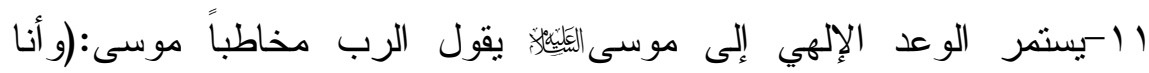
ظهرت لإبر اهيم و إسحاق ويعقوب بأني الإله على كل شيء، و أيضاً أقمت معهم عهدي القياً

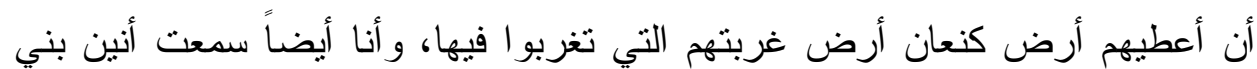

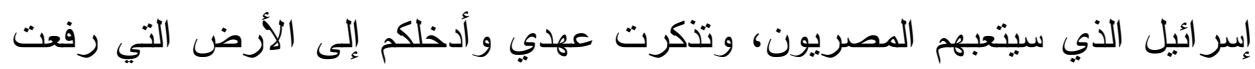

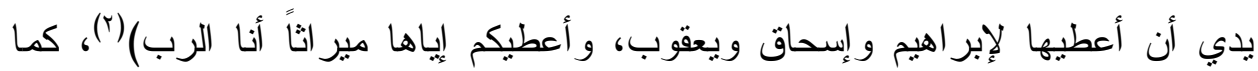

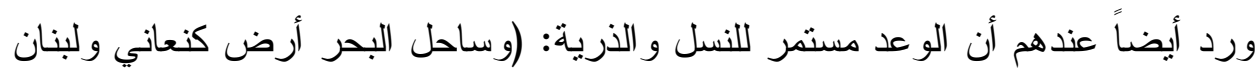

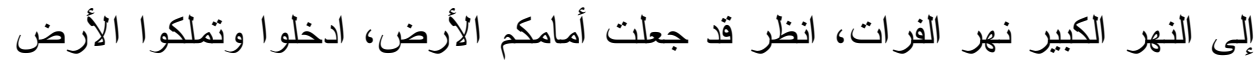
التي أقسم الرب لآبائكم إبر اهيم و إسحاق ويعقوب أن يعطيها لهم ولنسلهم من بعدهم) (ّ).

r ا - وينتقل الوعد بالأرض المقدة إلى داوود اللئليَّ): (وقد اختارني الرب إله

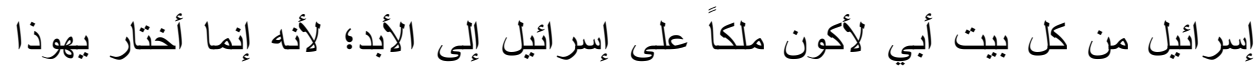

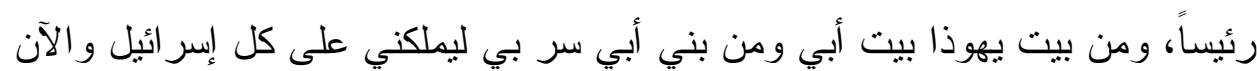

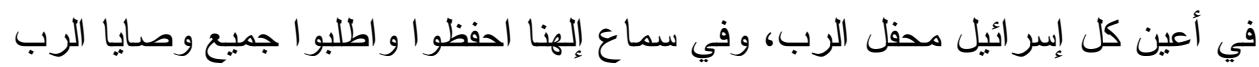

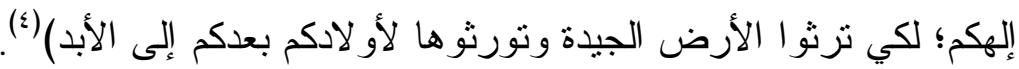

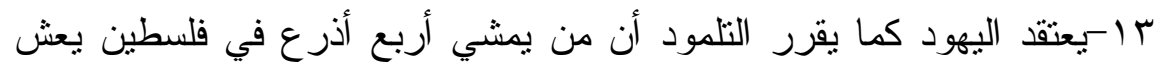
بلا ريب إلى أبد الآبدين، ومن يعش في فلسطين يطهر من الذنوب، ويرى أن حديث من يسكنون في فلسطين في حد ذاته تور اة(ه).

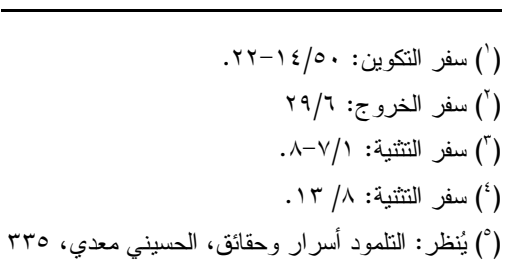


ثانياً: أقوال زعمائهم في عقيدة أرض الميعاد والناتجة عن أهداف دينية وسياسية و اقتصادية:

يتمسك اليهود بالنصوص التوراتية التي تؤيد مز اعمهم في إدعاء الوعد الإلهي

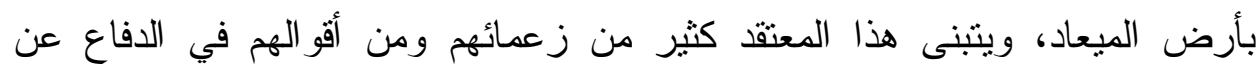
عقيدتهم في ذلك:

ا-يقول جريون رئيس وزراء الكيان الصهيوني الأسبق: "قد لا تكون فلسطين

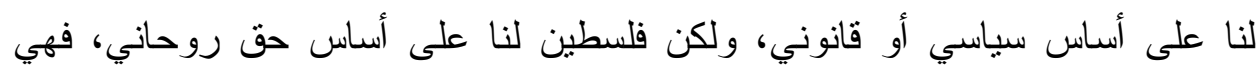

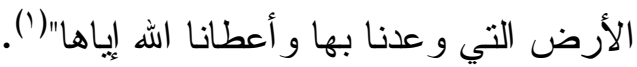

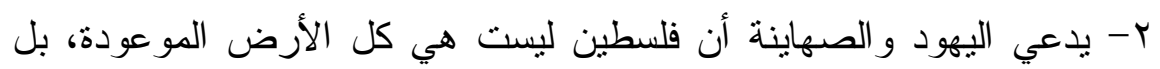
هناك أجز اء لم يتم الحصول عليها بعد، ويصرح مناجيم بيجن ('بذللك قائلاً:"إن إسر ائيل

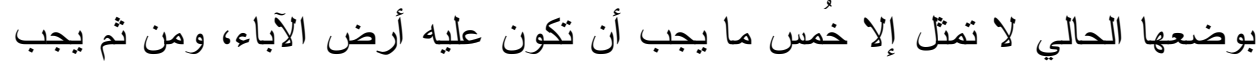

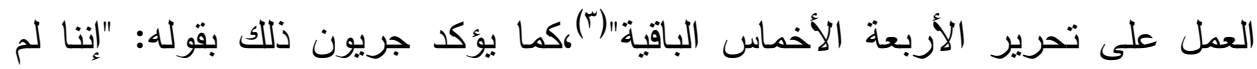

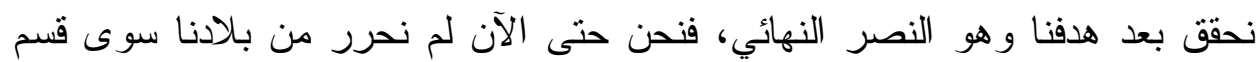

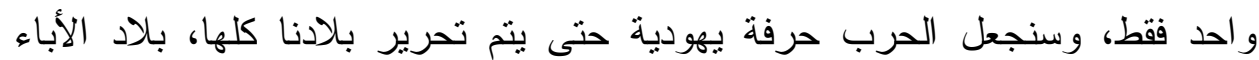

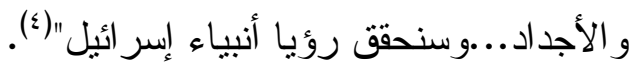

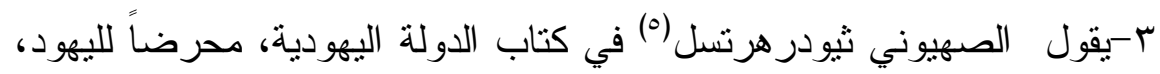

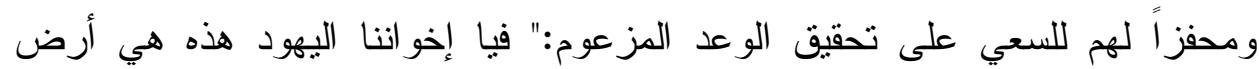

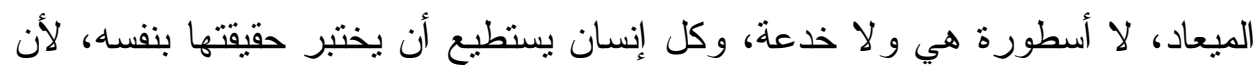

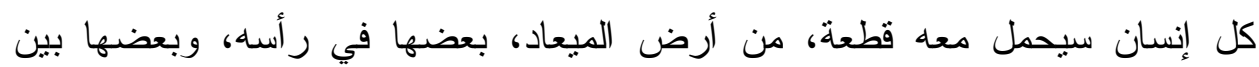

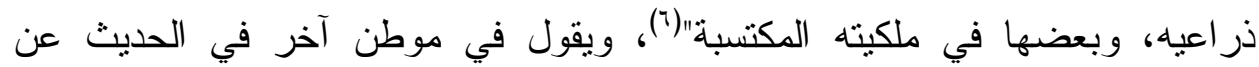

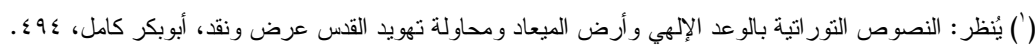

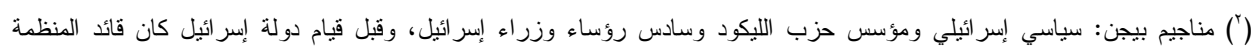

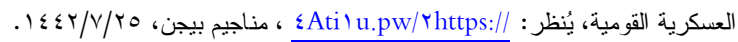

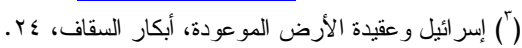

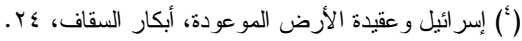

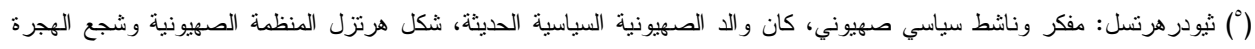

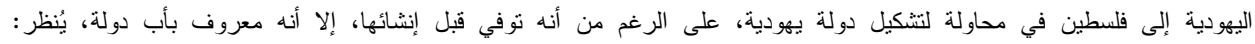


خططه ومشروعه في إنشاء دولة يهودية في فلسطين: "أما فلسطين فإنها وطننا

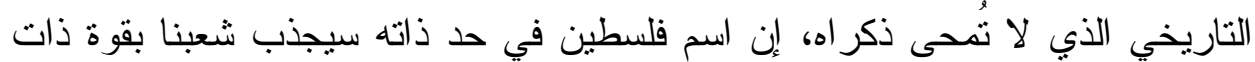

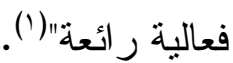

ومما يؤكد على أهدافهم الاستر اتيجية في ثنبي هذا المعتقد كثير من الأحداث و المؤتمر ات و القرارات التي لا يتسع المجال إلى ذكرها، وسأكتفي بذكر ثناثثة أمنلة فحسب :

ا-ربط علم إسر ائيل بأرض الميعاد، فالخطين الأزرقين يرمزان إلى النهرين، و النجمة السداسية التي بزعمون أنها تدل على تعاضد السلطة الدينية مع السلطة المدنية،

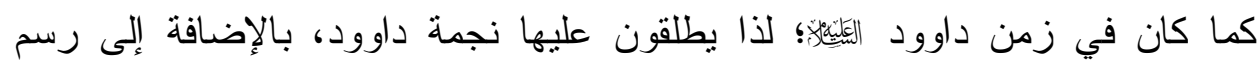
خريطة الأرض المزعومة من النيل إلى الفرات على دمود عملتهم النقدية(؟).

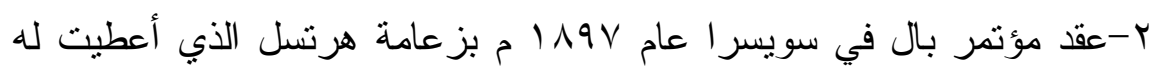

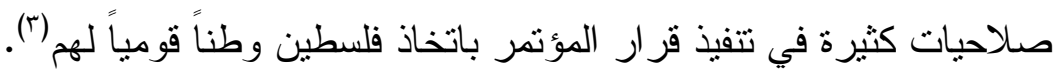
r-تدريس النصوص التوراتية والتلمودية التي تدعي حق اليهود في فلسطين و الأردن ولبنان وأجز اء من سوريا حتى حماة، و التأكيد في هذه الكتب على أن اليهود

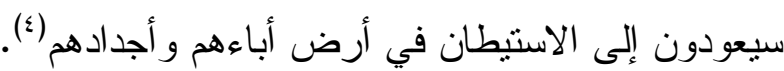

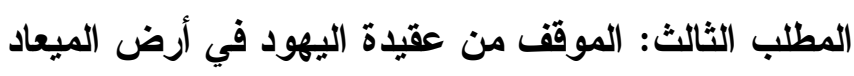

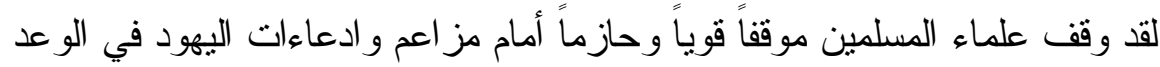

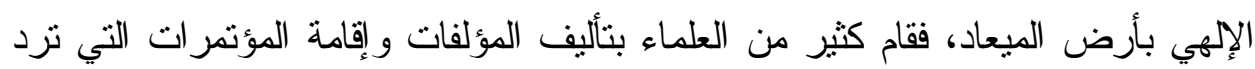
هذه الافتز اءات، وإثبات بطلان أقوالهم من خلال نصوص الوحني لوحين والحقائق التاريخية،

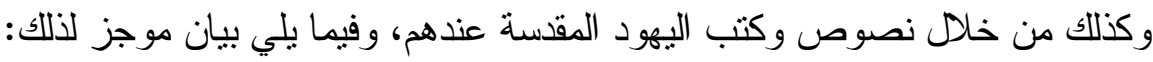
أولاً: لقد أثبت العلماء بطلان انتساب معظم اليهود المعاصرين إلى سلالة إسر ائيل

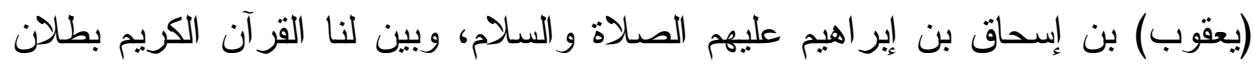

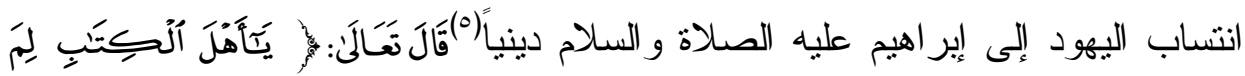




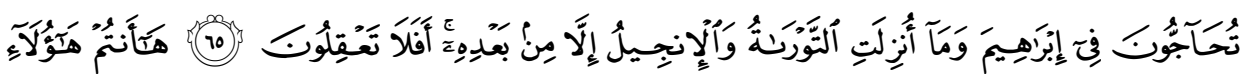

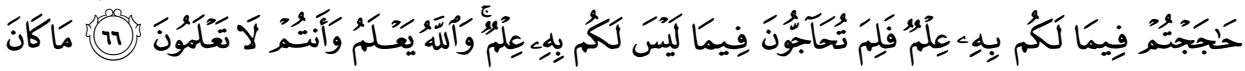

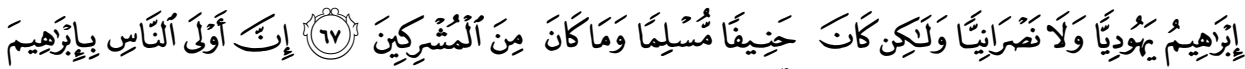

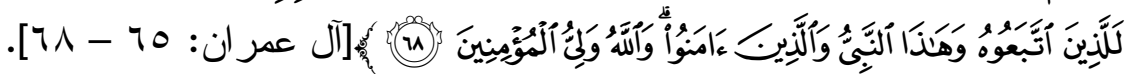
ثانياً: لقد وضح القرآن الكريم مزاعم اليهود حول ور اثثهم للأرض المبان الثباركة،

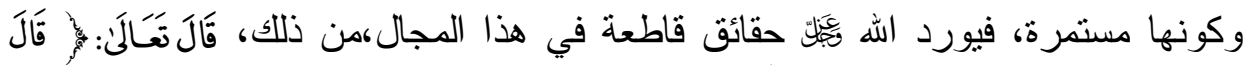

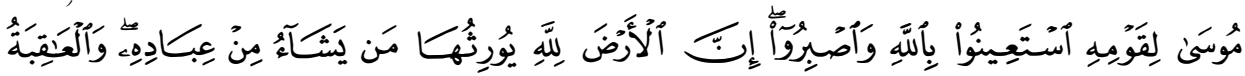

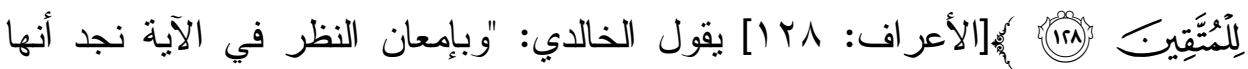

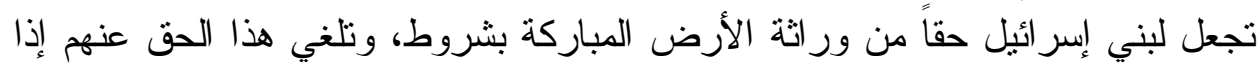

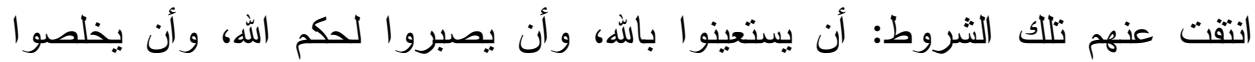

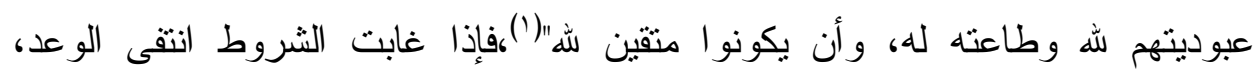

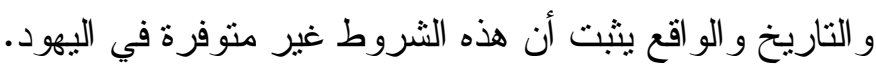

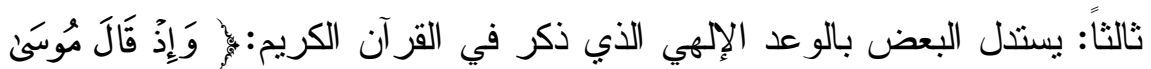

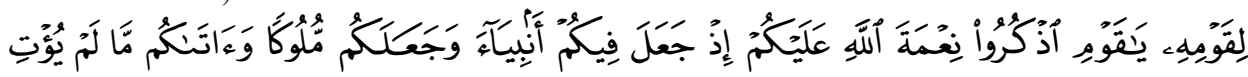

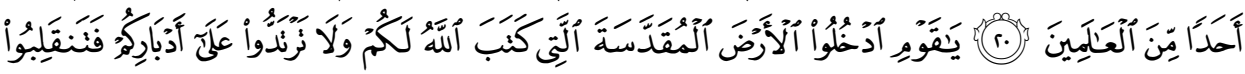

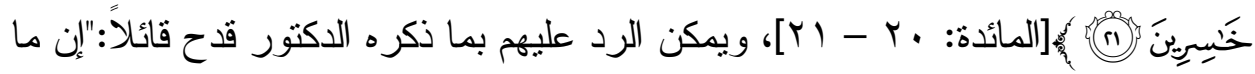

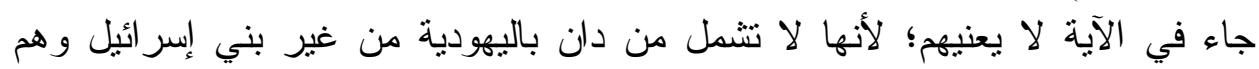

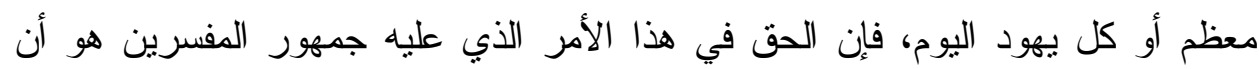

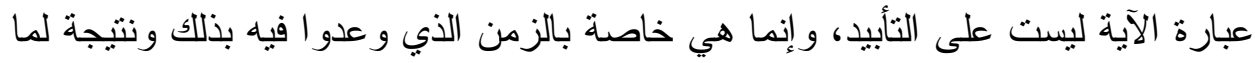

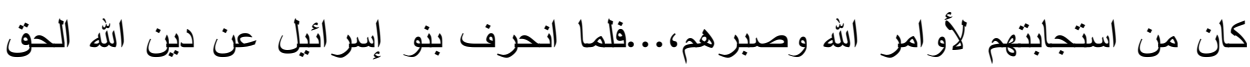

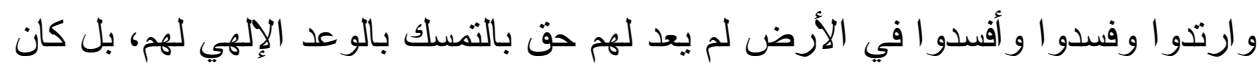

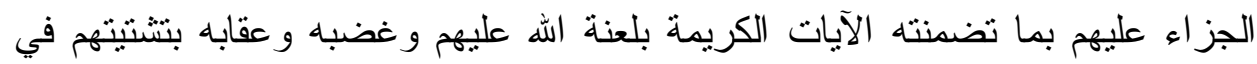

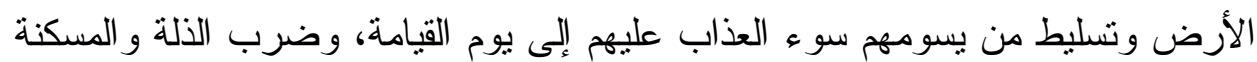

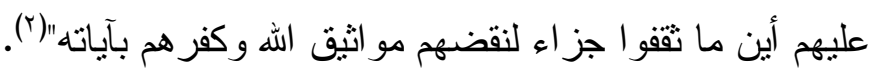


رابعاً: بالنسبة لما ورد في سفر التكوين: (لنسلك أعطي هذا البلد من نهر مصر

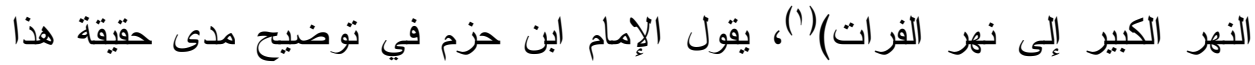

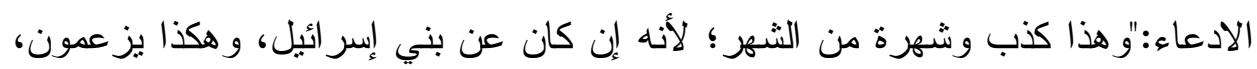

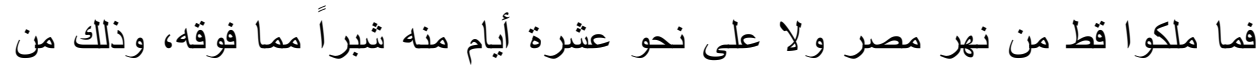
موقع النيل إلى قرب بيت المقس، وفي هذه المسافة الصحاري المشهورة المثتدة و الحضار، ثم دفج، وغزة، وعسقلان، وجبال الثراه، التي لم تزل تحاربهم طول مدة لته

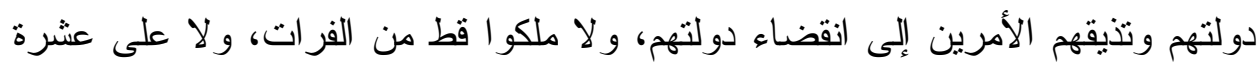

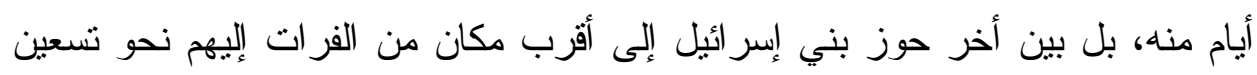

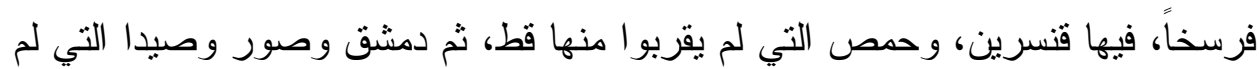

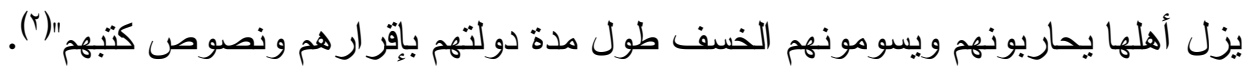

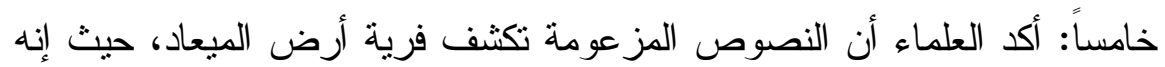

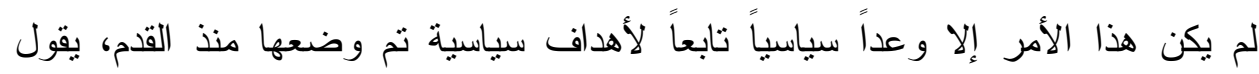

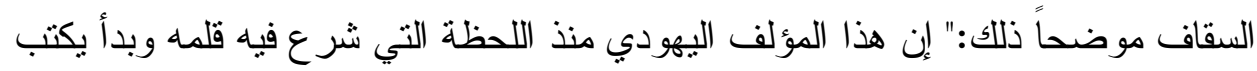

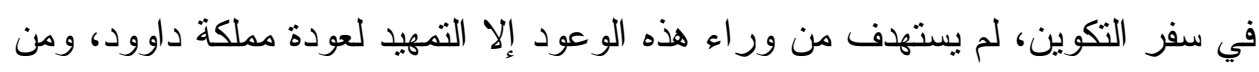

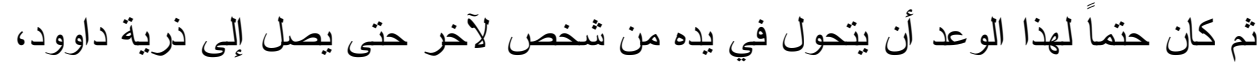

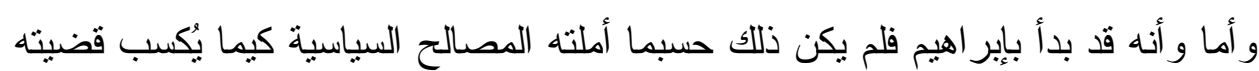

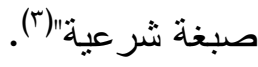
سادساً: إن لليهود مز اعم بالحق التاريخي لايهم، ويظهر بطلان ذلك من خلال الحقائق التاريخية التي تُبت وجود القبائل العربية من الكنعانيين و الفينقيين في فلسطين قبل ظهور اليهود بآلاف السنوات، ولم ينقطع وجود العرب واستمر ارهم في فلسطين إلى ولى

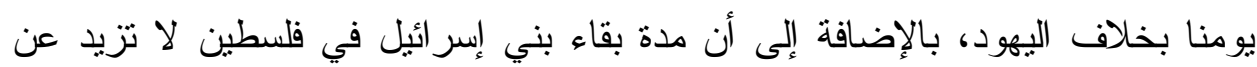

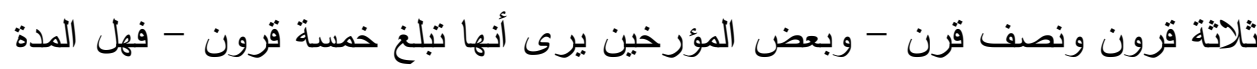
التي مكثو ها في فلسطين كافية في إثبات حقهم مقابل وجود العرب في فلسطين من قبلهم وبعدهم لمئات القرون (ء). 


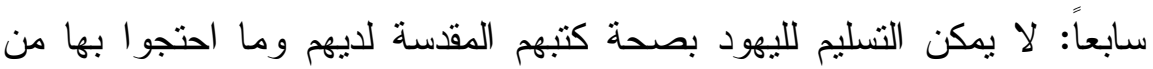

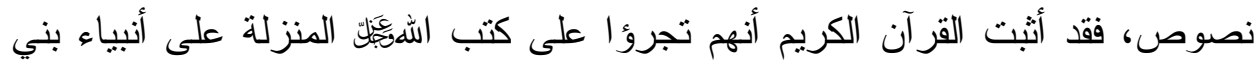

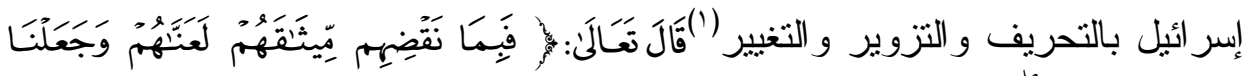

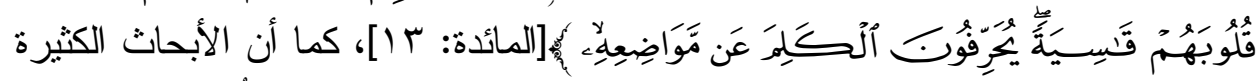
التي ظهرت في القرن الثامن عشر وازدادت في القرن التاسع عشر تُثبت أن الأسفار

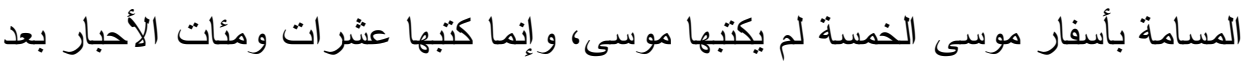

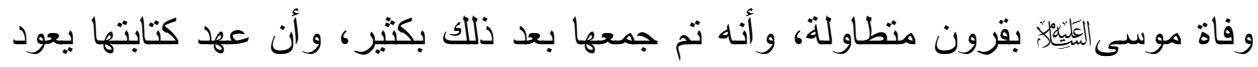

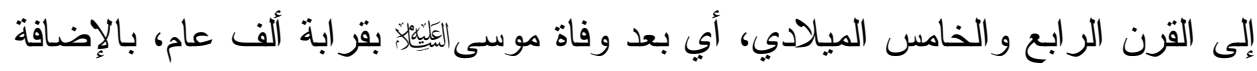

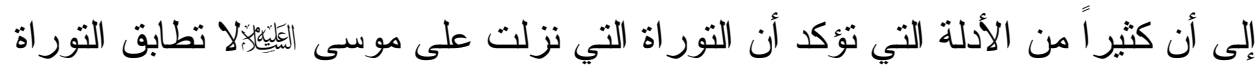

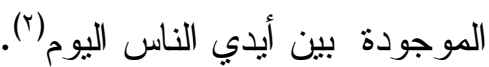
ولو يممنا وجوهنا شطر كتبهم، سيتبين بطلان ادعائهم من عدة جواتب، وذلك ائك بالإضافة لما ذكر سابقاً:

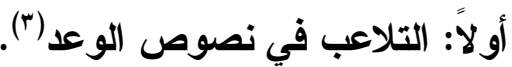

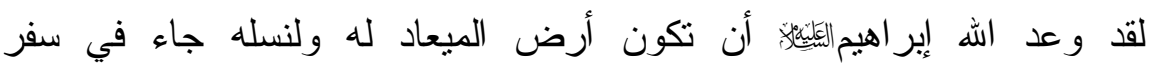
التكوين:(وقال الرب لإبر ام بعد اعتزال لوط عنه ارفع عينيك و انظر من الموضع الذي إني

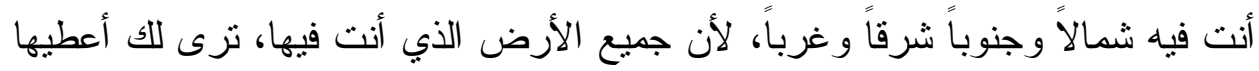

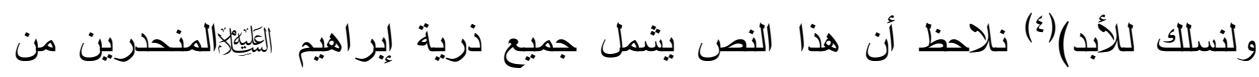
صلبه، سو اء ذرية ولده إسحاق أو ذرية ولده إسماعيل.

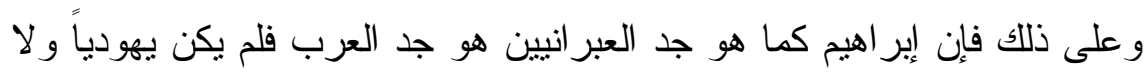

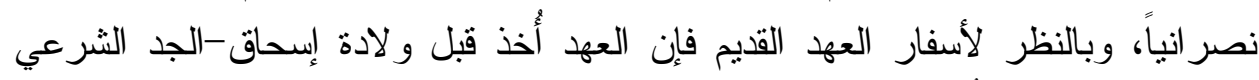

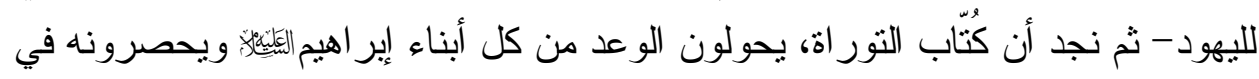

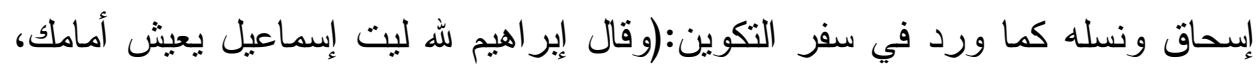

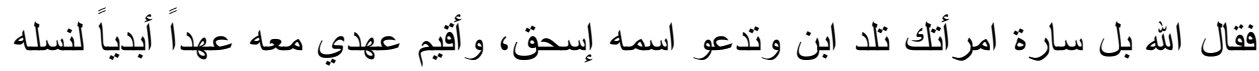

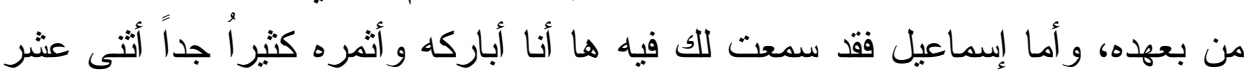


رئيساً يلد، و أجعله أمة كبيرة، ولكن عهدي أقيمه مع إسحق الذي تلاه سارة في هذا الوقت في السنة الآتية)(').

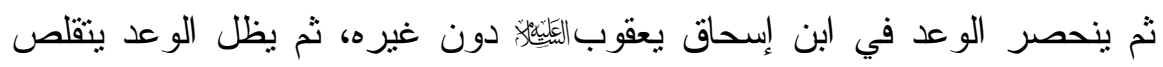

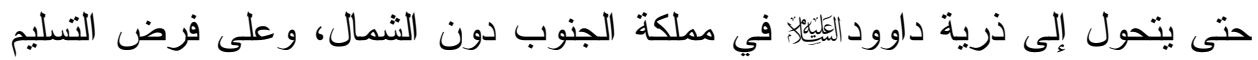

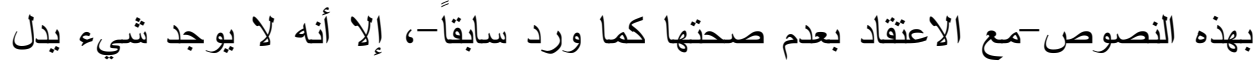
على الوفاء لإسحاق بهذا الوعد؛ لأن الملكية تحققت في ذرية إسماعيل، وقد ملكوا الأرض قبل الإسرائيليين، ولم ينقطع ملكهم حتى الآن و إن شاركهم الإسرائيليين؛ لإنى بالإضافة إلى أن الرب لم يذكر في سفر حزقيال بيت يهوذا، والخطاب كان لمملكة الثمال دون الجنوب، وهذا تلاعب وتتاقض و اضح في النصوص، لذإِ فإن هذا التحول من ابن لابن ومن مملكة لمملكة له هدف سياسي لوعد سياسي، تم دسه في التور اة. ثانياً:التناقض في حدود أرض الميعاد () إن من يتتبع نصوص الأسفار جميعها ويقابلها بالنصوص التي احتج بها اليهود في ادعائهم لأرض الميعاد وحدودها، وينتبع ما حدث لبني إسر ائيل والأحداث التاريخية المصاحبة لذلك قديماً وحديثاً ويُمعن النظر في عبارة (من نهر مصر إلى التى النهر الكبير

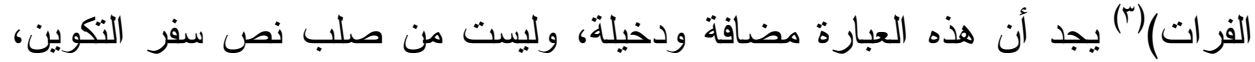

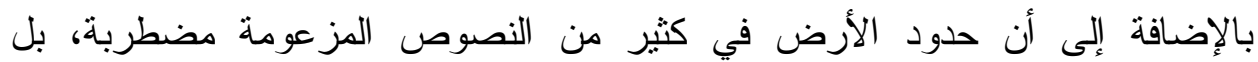
متضاربة يُسقط بعضها بعضاً، وحاثنا لله أن يكون هذا وحياً أوحاه الله ومن ذلك:

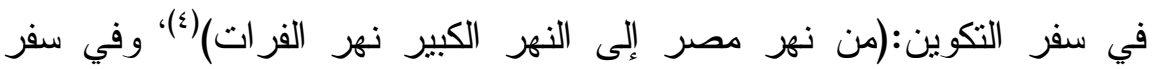

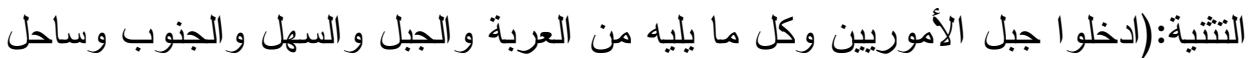

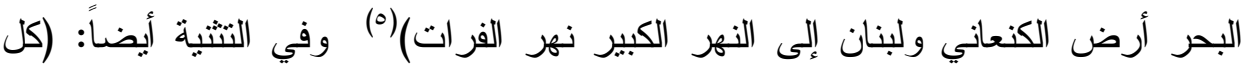
مكان تدوسه بطون أقدامكم يكون لكم من البرية ولبنان، من النهر نهر الفرات إلى إلى البحر

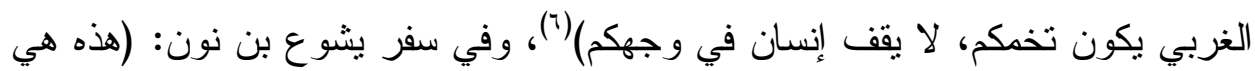
الأرض الباقية كل دائرة الفلسطين من الثيحور الذي هو أمام مصر إلى تخم عفرون 
شمالاً، من التيمن ومغارة إلى أفيق، إلى تخم الأموريين وأرض الجبلين وكل لبنان نحو

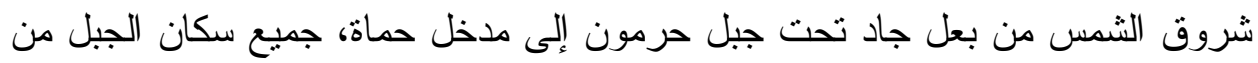

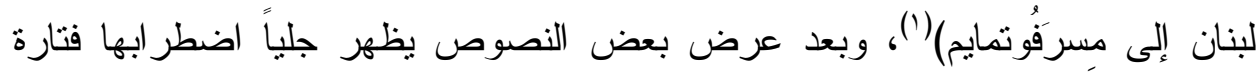
تتسع وتارة تضيق.

\section{ثالثاً: نقض اليهود لشروط الوعد عبر مراحل تاريخهم(؟) .}

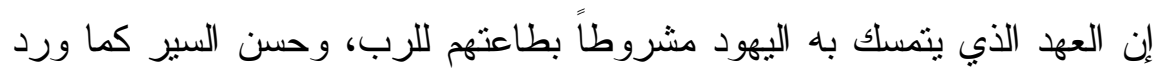

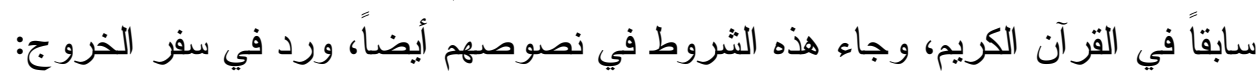
(فالآن إن سمعتم لصوتي وحفظتم عهدي تكون لي خاصة من بين جميع الشعوب، فإن لي كل الأرض، و أنتم تكونون لي مملكة وكعنة وأمة مقدسة) ().

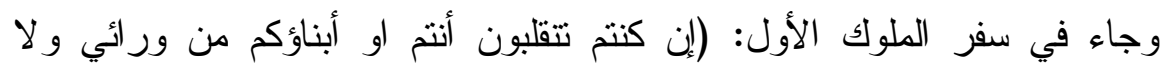
تحفظون وصاياب فرائضي التي جعلتها أمامكم بل تذهبون وتعبدون آلهة أخرى وتنجدون النهاء لها، فاني أقطع إسرائيل عن وجه الأرض التي أعطيتهم إياها و البيت الذي قدسته لأسهي

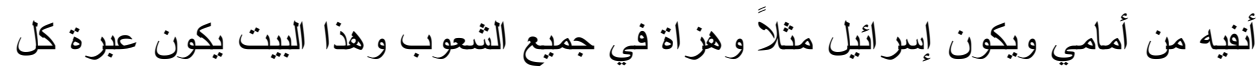

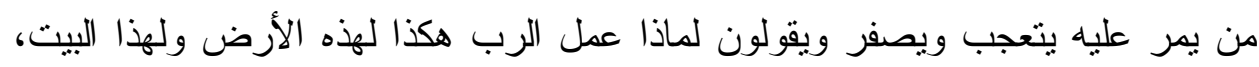

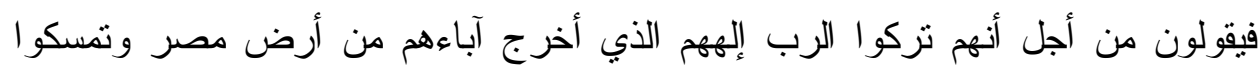
بآلهة اخرى وسجدو الها و عبدوها لذلك جلب الرب عليهم كل هذا الثر) (أ). فالرب حكم عليهم إن لم يحفظو ا فر ائضه وأحكامه ووصاياه فسيقطع نسل بني إسرائيل من الأرض، ويجعلهم عبرة لجميع الشعوب، ونلاحظ أن بني إسرائيل عبر مراحل

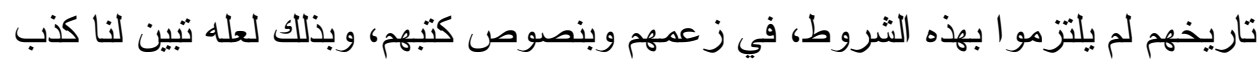

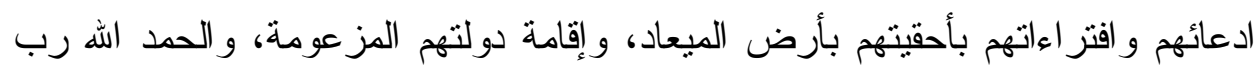

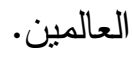




\section{الخاتمة}

الحمد اله الكريم المنان، و الصلاة و السلام على النبي المصطفى سيد ولا عدنان،

فإنني أحمد اله هيَّلَّ و أثنكره أن منّ عليّ بإتمام هذه الدراسة التي تناولت فيها

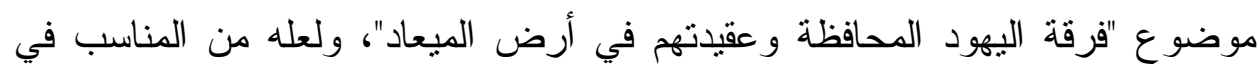
نهاية الدراسة أن أذكر أهم نتائجها وتوصياتها: النها:

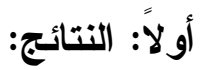

1-إن الفرق اليهودية الحديثة، ظهرت كنتيجة مباشرة أو غير مباشرة لحركتي التتوير و التحرير التي نشأت في القرن السابع عشر و الثامن عشر الميلاديين في أوربا.

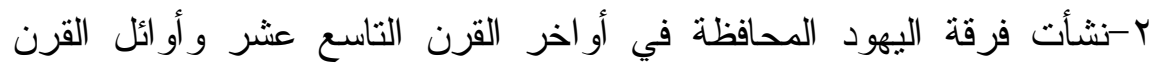
العشرين في الولايات المتحدة، لتسلك طريقاً وسطاً بين اليهودية الإصلاحية و اليهودية الأرثوذكسية.

ب-ظهرت فرقة اليهود المحافظة لسببين، أولاً: محاولة من جانب اليهودية للاستجابة لوضع اليهود في العصر الحديث في العالم الجديد، ثانياً: رد فعل لليهودية الإصلاحية أكثر من كونها رد فعل لليهودية الأرثوذكسية؛ لإن الإصلاحية اكتسحت

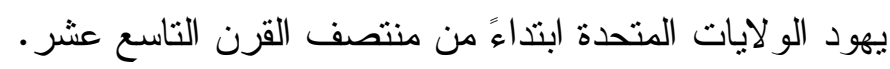

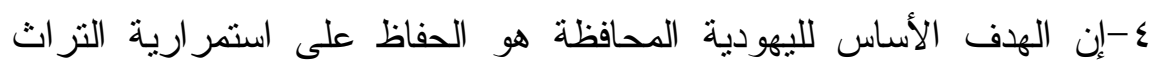

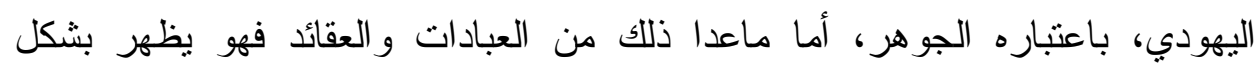
عضوي و تلقائي متجدد. 0- كما تهدف فرقة اليهود المحافظة لتتمية الشعور بالوحدة الجامعة لبني

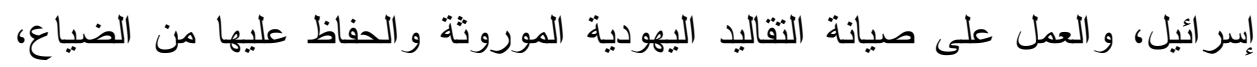

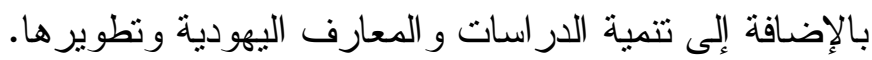
ج-من أبرز أعلام ومفكري فرقة اليهود المحافظة، زكريا فر انكل، إسكندر

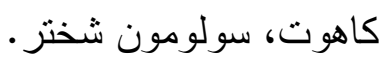
V-تذكر الإحصاءات نز ايد عدد اليهود المحافظين في أنحاء العالم، وخصوصاً

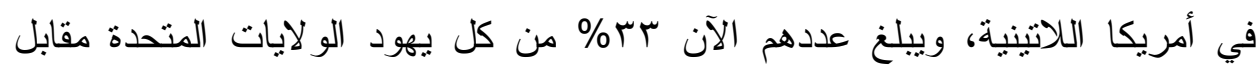

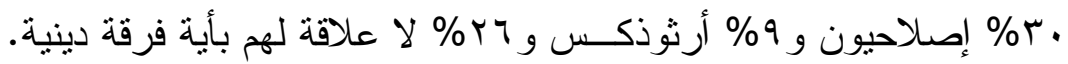


1-إن الجذور الفكرية بين الإصلاحية و المحافظة منمانلة، لأنهما يهدفان إلى حل

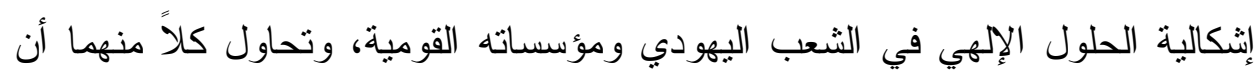
تصل إلى صياغة حديثة للبهودية عن طريق تبني مفهوم يُسمى (الروح).

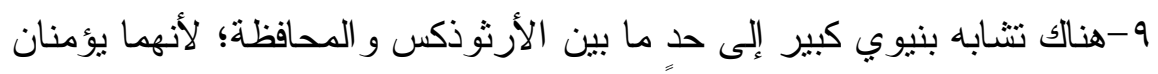

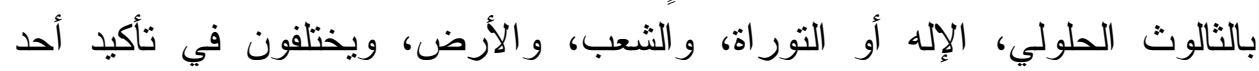

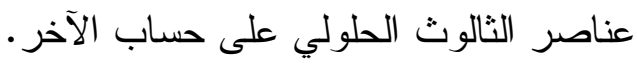
• إيؤمن المحافظة بالثالوث الحلولي، ويبرزون أهمية الثعب وتر اثله وتاريخه،

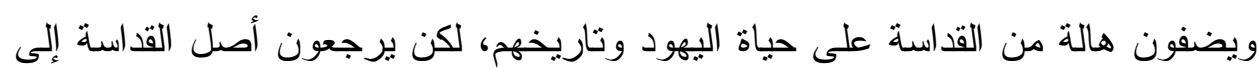

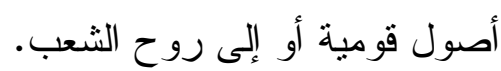
1ا-يعتقد المحافظون أن التلمود نتاج نقافي لابد الاستفادة من قيمته العامة في المو اقف الشعبية، ويرون أنه ليس مرسلاً من الإله.

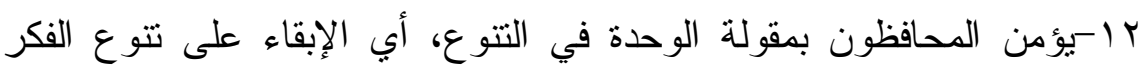
الديني و الحاجات المجتمعية لليهود ضمن إطار واحد، مع الحفاظ على الإشارة الدائمة الإنة في جميع الطقوس إلى تاريخ إسر ائيل الماضي و إلى عودتهم إلى وطنهم، و إعادة بناء ملكهم في صهيون. rا - تؤكد المحافظة على ضرورة الالتزام بشعائر أو امر اليهودية، لكنها أكثر تساهلاً في تأويلها لكيفية القيام بذلك. ع ا-إن الفكر الصهيوني يشبه في كثير من الوجوه فكر اليهود المحافظة،

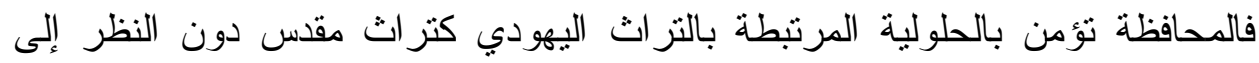

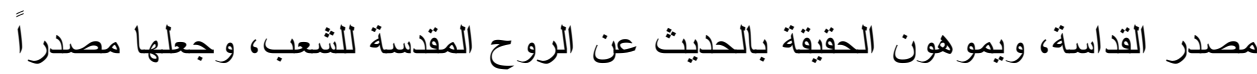
للقداسة بدلاً من الإله، وبذلك يظهر أن اليهودية المحافظة هي الحلولية اليهودية التقليدية بعد تقديم الجانب البشري على الجانب الإلهي، وهذا هو جوهر الصهيونية. 10-ريرتبط اليهود بعقيدة أرض الميعاد، التي يدينون بها، ويعملون من أجلها، ويستلون على حقهم فيها بنصوصهم المقدسة. 7 ا1أرض الميعاد هي أرض كنعان، وهي الأرض التي وعد اله بها إبر اهيم

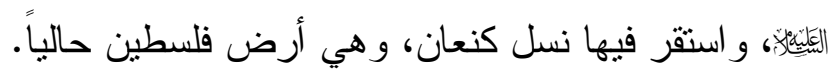


IV

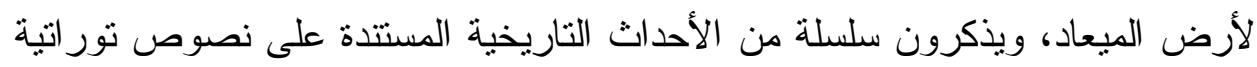

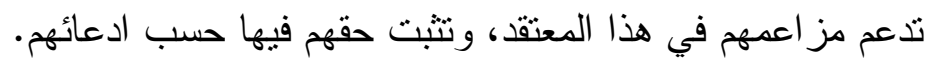

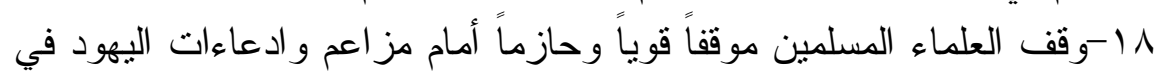

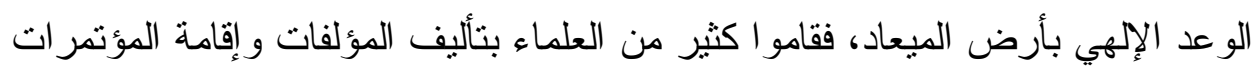

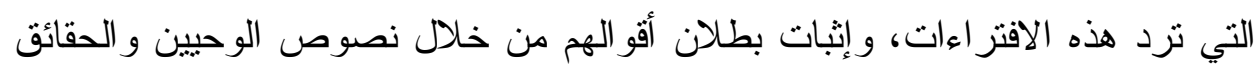
التاريخية، وكذلك من خلال كتبهم المقدسة.

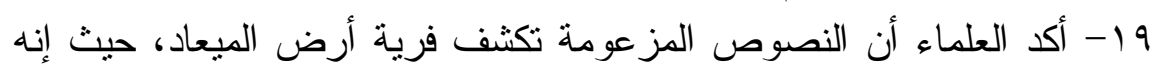

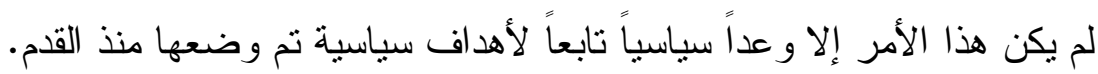

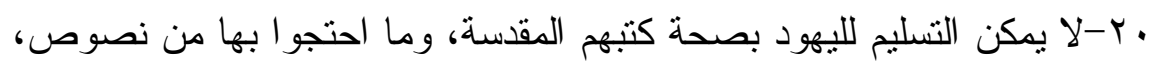

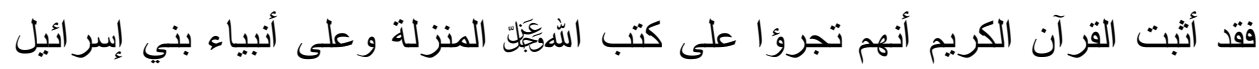
بالتحريف و التزوير و التغيير . اب-بظهر كذب ادعاء اليهود في عقيدة أرض الميعاد، من خلال اثبات تلاعبهم

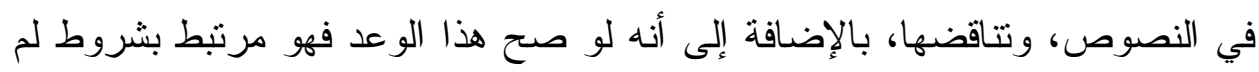
يلتزم بها اليهود. ثانياً:التوصيات:

ا-حث المختصين في علم الأديان على الاعتناء وبذل المزيد في الدراسات التي

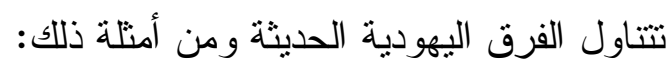
- العقائد المشنركة بين الفرق اليهودية الحديثة - العقائد المشتركة بين الفرف القديمة و الحديثة. - أثز الفرق القديمة على الفرق الحديثة. - العلاقة بين فرق اليهود الحديثة مع الفرق النصر انية. ץ-تدريس طلاب وطالبات التعليم العام و الجامعات قضية فلسطين، ولفئ وأبعادها الدينية و السياسية، ومحاو لات اليهود لبناء وطن قومي لهم فيها، وبيان خطر الصهيونية ووسائلهم في ذلك. هذا وفي نهاية المطاف أسأل اللهيَّلْ أن أكون قد هُديت ووفقت للوصول للمر اد،

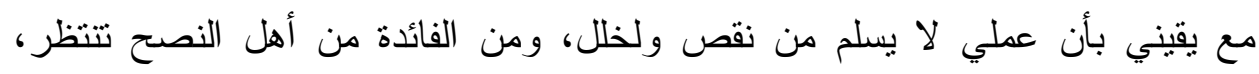
وصلى الله وبارك على سيدنا محمد و على آله وصحبه أجمعين. 
قائمة المر اجع و المصادر

$$
\begin{aligned}
& \text { أولاً: الكتب: } \\
& \text { 1-القر آن الكريم. }
\end{aligned}
$$

ץ-التلمود أسرار حقائق، الحسيني الحسيني معدى، دار الفكر العربي، دمشق، الطبعة الأولى،

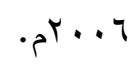

ب-التلمود تاريخه وتعاليمه، ظفر خان دار النفائس، بيروت، الطبعة الثانية، بحو ام.

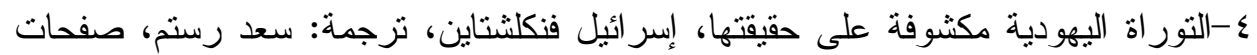

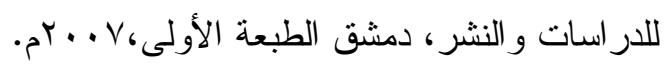

ه-الجانب الجدلي عند اليهود في الدفاع عن معتقداتهم وموقف علماء المسلمين منه دراسة تحليلية، حسام محمد، رسالة دكتور اه، جامعة العلوم الإسلامية العالمية، كلية الدراسات

$$
\text { العليا، عمان، } 17 \text { • ب بم. }
$$

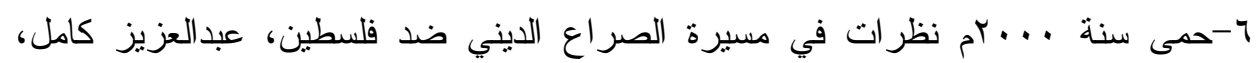

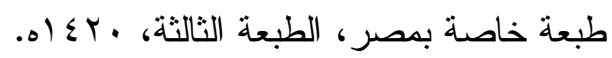

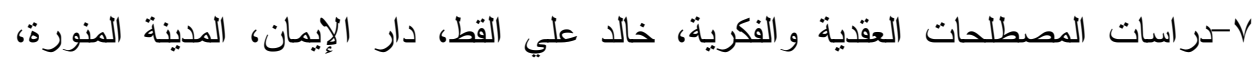

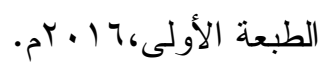

1-دليل التلمود مصطلحات ومفاهيم أساسية، عادين شتينزلنس، نزجمة مصطفى منصور .

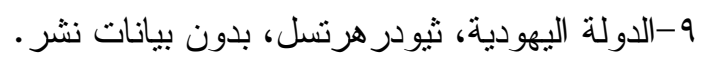

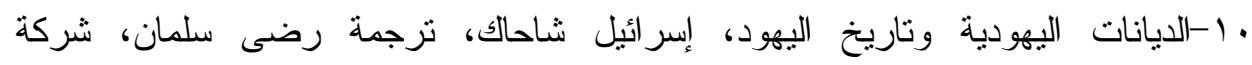

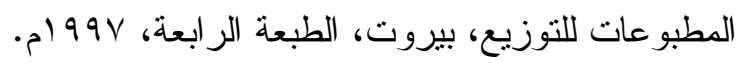

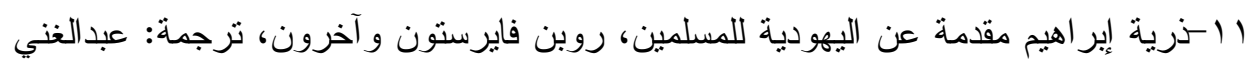
إير اهيم، معهد هاريت وروبرت للتفاهم الدولي بين الأديان اللجنة اليهودية الأمريكية.

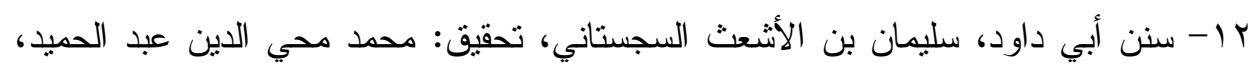
المكتبة العصرية، بيروت.

rا ا- سنن ابن ماجه، محمد بن يزيد القزويني، دار إحياء الكتب العربية، القاهرة.

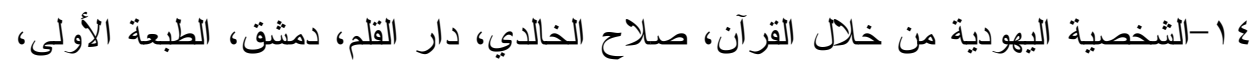
. $) \leqslant 19$ 
10- صحيح سنن أبي داود، محمد ناصر الدين الألباني، مكتب التزبية العربي لدول الخليج،

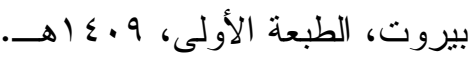

7 ا-العقائد المشتركة بين اليهود و النصارى وموقف الإسلام منها، خالد الصلاح، دار العلوم العربية، بيروت.

IV Vقيدة اليهود في الوعد بفلسطين عرض ونقد، محمد آل عمر، فهرسة مكتبة الملك فهد،

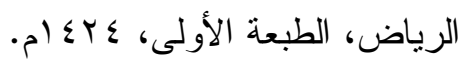
1 1-العلمانية الجزئية و العلمانية الثاملة، عبدالوهاب المسيري، دار الثروق، القاري، القاهرة، الطبعة

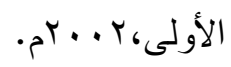

9 ا-الفصل في الملل والأهواء و النحل، علي بن أحمد بن سعيد بن حزم الأندلسي،ككتبة الخانجي، القاهرة.

• ب-قاموس الأديان الكبرى الثلاثة اليهودية المسيحية الإسلامية، نور الدين خليل، مؤسسة

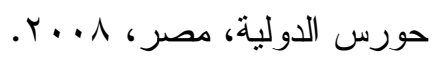

اب-قاموس الكتاب المقد، بطرس عبد الملك وآخرون، دار الثقافة، القاهرة، الطبعة

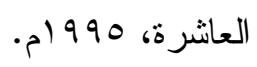

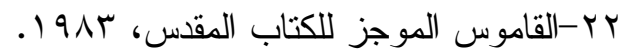

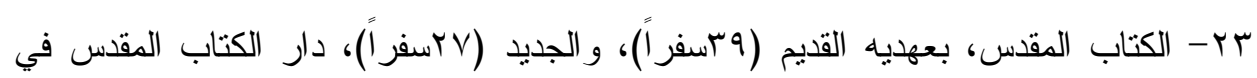

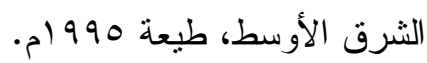

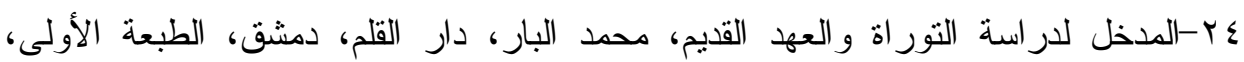
. 199 .

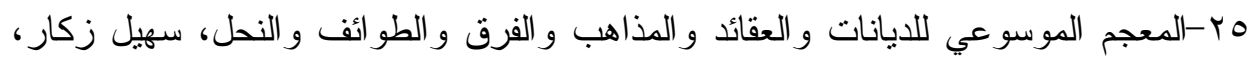

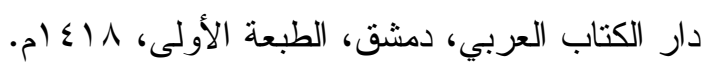

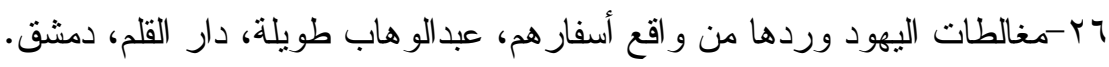

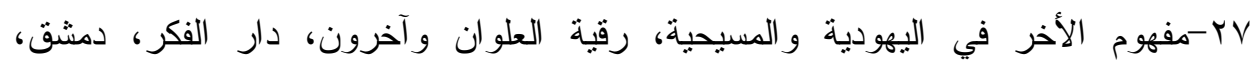
.

^ץ-الملل المعاصرة في الدين اليهودي، إسماعيل الفاروقي، معهد البحوث و الدراسات

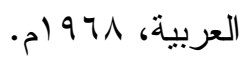

وץ-من هو اليهودي، عبدالوهاب المسيري، دار الشروق، القاهرة، الطبعة الثالثة، ؟ +. rم. 
• ب- موجز تاريخ اليهود و الرد على بعض مزاعمه الباطلة، محمود بن عبد الرحمن قدح، . 1 (19

اب-موسوعة المدن العربية، يحيى شامي، دار الفكر العربي، الرياض، الطبعة الأولى، . 99 rr- الموسوعة الميسرة في الأديان و المذاهب والأحزاب المعاصرة، مانع الجني، الندوة

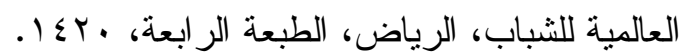

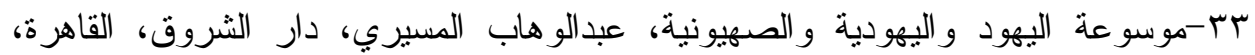

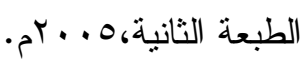

ع ب-نبوءات نهاية العالم عند الإنجيلين وموقف الإسلام منها، محمد عزت، دار البصائر، القاهرة، الطبعة الأولى، 9 9. - بام.

هب-النصوص التوراتية بالوعد الإلهي وأرض الميعاد وتهويد القدس عرض وض ونقد، مجلة

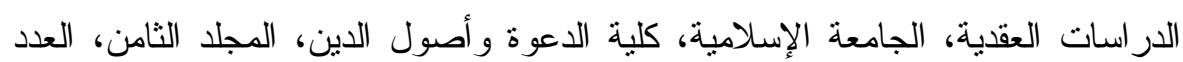

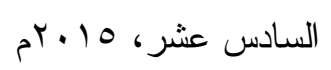

بس-اليهودية بين الوحي الإلهي و الانحراف البشري، فرج الله عبد الباري، دار الأفاق العربية،

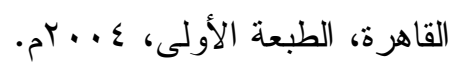

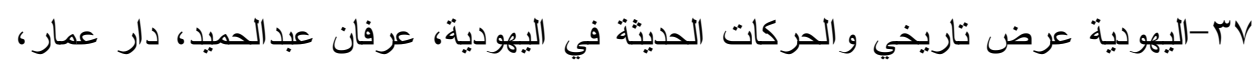

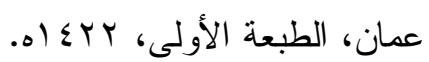

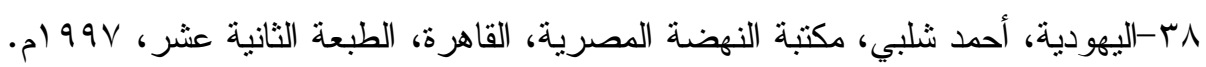

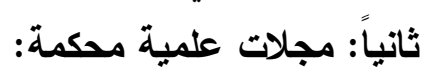
ا-الفرق اليهودية المعاصرة دراسة وصفية، المجلة العلمية لكلية أصول الدين و الدعوة،

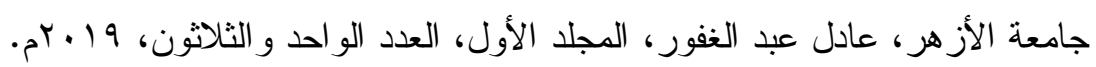

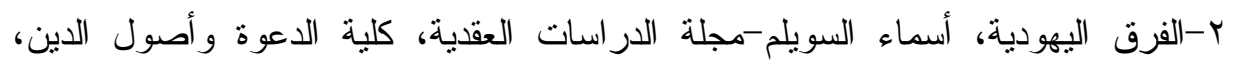

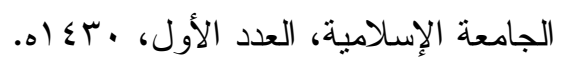
r-الفرق اليهودية وأثار ها في الو اقع اليهودي المعاصر، ، محمد كركور، حولية كلية الدعوة، 
ع-وثائق الجينزا اليهودية وأهميتها كمنتج سياحي فريد، محمد حسن وآخرون، المجلة

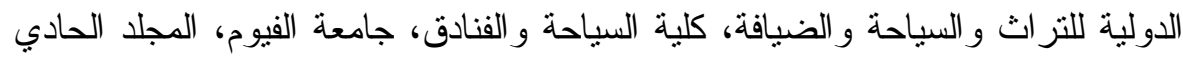

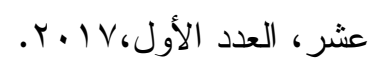

ه-و اقع التجمعات اليهودية في الولايات المتحدة الأمريكية، قيس مر اد، مركز الأبحاث في

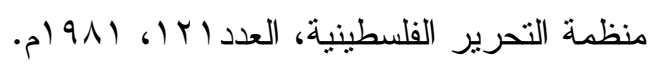
ثالثاً: المواقع الإكترونية:

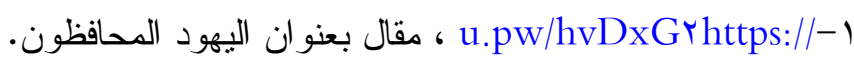

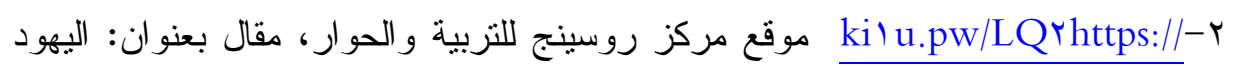
الإصلاحيين و اليهود المحافظين. r ع - u.pw/BItfprhttps:/ ، مقال بعنو ان إسر ائيل شاحاك. 
